In Press, Journal of Environmental Quality, Vol. 31, no. 3, 2002.

\title{
Transport And Fate Of Nitrate In A Glacial Outwash Aquifer In Relation To Ground-Water Age, Land Use Practices and Redox Processes
}

\author{
Larry J. Puckett ${ }^{*}$ and Timothy K. Cowdery
}

\begin{abstract}
A combination of ground-water modeling, chemical and dissolved gas analyses, and chlorofluorocarbon age dating of water was used to determine the relation between changes in agricultural practices, and $\mathrm{NO}_{3}{ }^{-}$concentrations in ground water of a glacial outwash aquifer in west-central Minnesota. The results revealed a redox zonation throughout the saturated zone with oxygen reduction near the water table, $\mathrm{NO}_{3}{ }^{-}$ reduction immediately below it, and then a large zone of ferric iron reduction, with a small area of sulfate $\left(\mathrm{SO}_{4}{ }^{2-}\right)$ reduction and methanogenesis $\left(\mathrm{CH}_{4}\right)$ near the end of the transect. Analytical and NETPATH modeling results supported the hypothesis that organic carbon served as the electron donor for the redox reactions. Denitrification rates were small, 0.005 to $0.047 \mathrm{mmol} \mathrm{NO}_{3}{ }^{-} \mathrm{yr}^{-1}$, and were limited by the small amounts of organic carbon, 0.01 to 1.45 percent. In spite of the organic carbon limitation, denitrification was virtually complete because residence time is sufficient to allow even slow processes to reach completion. Ground-water sample ages showed that maximum residence times were on the order of 50-70 years. Reconstructed $\mathrm{NO}_{3}{ }^{-}$concentrations, estimated from measured $\mathrm{NO}_{3}{ }^{-}$and dissolved nitrogen gas showed that $\mathrm{NO}_{3}{ }^{-}$ concentrations have been increasing in the aquifer since the 1940s have been above the $714 \mu \mathrm{mol} \mathrm{L}{ }^{-1}$ maximum contaminant level at most sites since the mid- to late-1960s. This increase in $\mathrm{NO}_{3}^{-}$has been accompanied by a corresponding increase in agricultural use of fertilizer, identified as the major source of $\mathrm{NO}_{3}{ }^{-}$to the aquifer.
\end{abstract}

\section{INTRODUCTION}

Nitrate is recognized as the most ubiquitous contaminant of shallow aquifers (Postma et al., 1991; Spalding and Parrott, 1994). This ground-water contamination provides cause for concern because elevated concentrations of $\mathrm{NO}_{3}{ }^{-}$have been associated with human health risks (Spalding and Parrott, 1994), and when $\mathrm{NO}_{3}{ }^{-}$discharges to surface waters it may contribute to eutrophication. Consequently, there has been growing interest in processes and conditions that lead to natural remediation of $\mathrm{NO}_{3}{ }^{-}$contaminated aquifers. The primary pathway for removal of $\mathrm{NO}_{3}{ }_{3}^{-}$from ground water is denitrification, wherein nitrogen serves as the terminal electron acceptor following the general reaction:

$$
2 \mathrm{NO}_{3}{ }^{-}+12 \mathrm{H}^{+}+10 e^{-} \rightarrow \mathrm{N}_{2}+6 \mathrm{H}_{2} \mathrm{O}
$$

Larry J. Puckett, U.S. Geological Survey, 413 National Center, Reston, VA 20192; and Timothy K. Cowdery, U.S. Geological Survey, 2280 Woodale Road, Mounds View, MN 55112. "Corresponding author (Ipuckett@usgs.gov). 
In Press, Journal of Environmental Quality, Vol. 31, no. 3, 2002.

Bacteria that derive energy from the oxidation of a reduced species typically mediate this reaction. Organic carbon (Gillham and Cherry; 1978, Morris et al., 1988; Starr and Gillham, 1993) is a common electron donor in the heterotrophic denitrification process:

$$
5 \mathrm{CH}_{2} \mathrm{O}+4 \mathrm{NO}_{3}^{-} \rightarrow 2 \mathrm{~N}_{2}+4 \mathrm{HCO}_{3}^{-}+\mathrm{CO}_{2}+3 \mathrm{H}_{2} \mathrm{O}
$$

Alternatively, other reduced species such as ferrous iron in pyrite $\left(\mathrm{FeS}_{2}\right)$ and silicate minerals such as pyroxenes and amphiboles, can serve as the electron donor in the autotrophic denitrification process (Kolle et al., 1983; Strebel et al., 1985; van Beek et al., 1988; Postma et al., 1991; Bohlke and Denver, 1995):

$$
10 \mathrm{Fe}^{2+}+2 \mathrm{NO}_{3}^{-}+14 \mathrm{H}_{2} \mathrm{O} \rightarrow \mathrm{N}_{2}+10 \mathrm{FeOOH}+18 \mathrm{H}^{+}
$$

It is significant that in all these reactions, $\mathrm{NO}_{3}{ }^{-}$is converted from a potentially harmful form to a benign form as $\mathrm{N}_{2}$ gas. Under most conditions, the $\mathrm{N}_{2}$ gas produced as the result of denitrification will remain in solution until the ground water discharges to a surface-water body and equilibrates with the atmosphere (Heaton and Vogel, 1981; Blicher-Mathiesen, 1998). By measuring this excess $\mathrm{N}_{2}$, it is possible to estimate the amount of $\mathrm{NO}_{3}{ }^{-}$originally present in the ground water (Heaton and Vogel, 1981; Vogel et al., 1981; Wilson, et al., 1990; Smith et al., 1991; Bohlke and Denver, 1995; BlicherMathiesen, 1998; Modica et al., 1998).

Dissolved oxygen $\left(\mathrm{O}_{2}\right)$ is thermodynamically favored over $\mathrm{NO}_{3}{ }^{-}$as the terminal electron acceptor in the oxidation of organic carbon (Stumm and Morgan, 1981; Chapelle et al., 1995). When virtually all the available $\mathrm{O}_{2}$ is consumed, denitrification becomes the terminal electron accepting process, leading to lower $\mathrm{NO}_{3}{ }^{-}$concentrations as well. Once most of the available $\mathrm{NO}_{3}{ }^{-}$is consumed, bacteria utilize manganese oxides and then iron oxides as terminal electron acceptors. Under very strong reducing conditions, bacteria capable of deriving energy from sulfate reduction and methanogenesis will be favored. The net result of this evolution of water chemistry is a predictable sequence where $\mathrm{O}_{2}$ and then $\mathrm{NO}_{3}{ }^{-}$are consumed, manganese and iron come into solution, sulfate is consumed and sulfide may come into solution, and finally methane may appear in solution (Chapelle et al., 1995). This predictable sequence, under some conditions, may allow determination of the redox state of the aquifer at various points along a flow path, and prediction of the fate of $\mathrm{NO}_{3}{ }^{-}$in the aquifer. Few studies have conducted a complete, simultaneous analysis of the various nitrogen species, particularly $\mathrm{N}_{2}$, coupled with an analysis of the redox processes involved, leaving many questions unanswered with respect to the true fate of $\mathrm{NO}_{3}{ }^{-}$.

In addition to denitrification, other factors may affect spatial and temporal patterns of $\mathrm{NO}_{3}{ }^{-}$along ground-water flow paths. For example, inputs of nitrogen in atmospheric deposition, fertilizer, and animal wastes have increased markedly over the past 5 decades (Puckett, 1995). When ground waters of increasing age are analyzed, the older waters will appear to have less $\mathrm{NO}_{3}{ }^{-}$simply because they received less at the time of recharge. Also, conditions favoring denitrification can be patchy in some environments (Addy et al., 1999; Gold et al., 1998; Jacinthe et al., 1998) making it 
In Press, Journal of Environmental Quality, Vol. 31, no. 3, 2002.

possible to have discordant $\mathrm{NO}_{3}{ }^{-}$concentrations in an aquifer. All of these conditions make it necessary to develop a complete understanding of both the hydrogeologic and biogeochemical processes involved in the transport and fate of $\mathrm{NO}_{3}{ }^{-}$.

Puckett et al. (1999) presented a mass-balance analysis for the Otter Tail aquifer system in west-central Minnesota and concluded that although the $212.4 \mathrm{~km}^{2}$ system receives about 2000 metric tons of nitrogen each year, only 229 metric tons (11 percent) actually enters the ground-water system. Their analysis indicated that about 181 metric tons (44 percent) of the excess nitrogen leaving the root zone was removed through denitrification. Their evidence for denitrification was based on the loss of nitrate from the system in the mass-balance model as well as an analysis of the oxidationreduction (redox) conditions in ground water sampled as part of the study. However, that analysis focused entirely on landscape and watershed processes, including the upper 2 meters of the shallow ground-water system; no information was provided on the transport and fate of nitrogen as it moved through the aquifer. Because of the potentially harmful nature of $\mathrm{NO}_{3}{ }^{-}$, it is important to understand its transport from the shallow ground-water system into deeper portions of aquifers where most drinking water well screens are located. Also, developing a complete understanding of the biogeochemical reactions involved in the transformation of $\mathrm{NO}_{3}{ }^{-}$to other forms may allow us to more accurately predict when and where drinking water supplies may be contaminated.

In this paper, we present the results of a study designed to examine the hydrogeologic and biogeochemical processes controlling the evolution of water chemistry along flow paths of a representative cross-section within the Otter Tail aquifer studied by Puckett et al. (1999). We examine the hypothesis that denitrification is responsible for the loss of $\mathrm{NO}_{3}{ }^{-}$and further that it is driven by oxidation of organic matter. We also consider the hypothesis that changes in concentrations of $\mathrm{NO}_{3}{ }^{-}$are a function of changes in agricultural practices over time and, therefore, the age of water sampled along the transect. In evaluating these hypotheses, we develop an analysis of the transport and fate of the major nitrogen species, the redox reactions involved, and the age-distribution of waters along the transect.

\section{STUDY AREA}

This study was conducted in Otter Tail County in west-central Minnesota, USA (Figure 1) in a $36 \mathrm{~km}^{2}$ subunit of the Otter Tail outwash aquifer north of the Otter Tail River near Perham. The Otter Tail outwash aquifer consists mostly of fine to coarse, fairly wellsorted sand, but also contains some gravel and silt. Cowdery (1995) reported that the outwash material consisted of $21 \%$ gravel, $45 \%$ coarse sand, $27 \%$ medium sand, and $7 \%$ fine sand and silt. Aquifer thickness is generally about $18 \mathrm{~m}$ but, may be over $30 \mathrm{~m}$ in places (Reeder, 1972). It was deposited by meandering debris-laden streams flowing from the disintegrating margin of the Des Moines glacial lobe sometime between 14,000 and 12,000 years BP (Wright, 1972). After the outwash sands were deposited, stagnant ice blocks within the aquifer melted, forming the abundant lakes and wetland depressions common throughout the area (Goldstein, 1985). 
In Press, Journal of Environmental Quality, Vol. 31, no. 3, 2002.

Recharge to the aquifer occurs over much of its area from snowmelt and rainfall and was estimated at $17.7 \mathrm{~cm} \mathrm{yr}^{-1}$ on the basis of a hydrologic budget and analyses of ground-water hydrographs (Cowdery, 1997; Puckett et al., 1999). Ground-water flow is generally from the higher elevations of the moraines on the west, north, and east sides of the aquifer toward the Otter Tail River-chain of lakes in the center of the aquifer. Wetlands, lakes and streams are in hydraulic connection with the ground water. Water loss from the aquifer is through discharge to the Otter Tail River, lakes, wetlands, pumping from wells, and through evapotranspiration.

Climate of the West Central Minnesota climate division has been described as subhumid continental and annual average temperature and precipitation in the area during the 30-year period from 1966 to 1995 was $5.6^{\circ} \mathrm{C}$ and $68 \mathrm{~cm}$, respectively (Stoner et al., 1993). Open water evaporation in the study area exceeds precipitation by about $10 \mathrm{~cm}$ $\mathrm{yr}^{-1}$ (Winter and Woo, 1990) consequently ground-water recharge occurs primarily during spring snowmelt when potential evaporation is small. Historically the study area was prairie, surrounded by hardwood and conifer forests on the morainal uplands however, at the time of the study, approximately 73 percent of the land was cropland.

Fertilizer nitrogen use for agricultural purposes in Otter Tail County (Figure 2) increased from about 28 metric tons in 1945 to about 13000 metric tons in 1994 (Jerald Fletcher, 1996, West Virginia University, written communication). A major step change in the application rate occurred about 1967 and the rate of increase has been essentially linear since about 1970. Over half of the total amount of nitrogen used during the 19451994 period has been applied since 1982.

\section{METHODS}

\section{Study Design}

Piezometers were installed at 5 locations along a $5 \mathrm{~km}$ transect, beginning near the northeastern edge of the aquifer and ending at the Otter Tail River to the southwest (Figure 1,3). This transect was chosen after examination of a water-table map developed from ground-water measurements made in wells in the area and from Reeder (1972). The 5 sites were chosen to provide roughly equidistant sampling points along the transect, although access limitations dictated that some sites were spaced closer than others. At three locations multiple piezometers were installed in a nest to define vertical gradients in the flow system. Screens were positioned to allow sampling of recently recharged ground water just below the water table at each site. Multiple screened intervals were positioned at 4 other depths at OF1, the most down gradient site, and at a deep and intermediate depth position at OF3, roughly at the midpoint of the transect. An additional deep screened interval was installed at site OF2 to provide more detail in that portion of the aquifer. The resulting distribution of sampling points was concentrated in the lower half of the transect where we expected the greatest age distribution and variability in ground-water concentrations due to biogeochemical evolution along longer flow paths. 
In Press, Journal of Environmental Quality, Vol. 31, no. 3, 2002.

Piezometers installed for the study were made of $5-\mathrm{cm}$ inside-diameter, polyvinyl chloride (PVC) pipe with slotted PVC screens 1.5 meters $(\mathrm{m})$ long; the exceptions being site OF3S which was $3 \mathrm{~m}$ long and sites OF1A, OF1B, and OF1C which were $0.76 \mathrm{~m}$ long. Longer screens were used in locations where extreme fluctuations in water table elevations were expected. After the PVC pipe was set, the hollow-stem auger flights were removed, allowing the aquifer formation to collapse around the screen. Piezometers were then sealed with at least $0.6 \mathrm{~m}$ of bentonite pellets and drill cuttings were used to fill the annulus to within $0.6 \mathrm{~m}$ of land surface. A 2-m long, steel protection pipe was set in concrete around the well and closed with a locking cap. Between well sites, the power auger was steam-cleaned to prevent cross-contamination. Piezometers were developed until they supplied clear water at a rate of at least $2 \mathrm{~L} \mathrm{~min}$ 1. No water was introduced into the well except deionized water where necessary for development.

\section{Hydrologic Modeling}

The ground-water flow models MODFLOW (McDonald and Harbaugh, 1988; Harbaugh and McDonald, 1996) and MODPATH (Pollock, 1989) were used to develop a 3dimensional steady-state flow model of the study area, delineate flow paths, and estimate ground-water travel times. A 3-layer model was constructed for a $26.7-\mathrm{km}^{2}$ portion of the study area using approximately 100 by $100 \mathrm{~m}$ cell dimensions. The model was based on a detailed study of the physical and hydrologic characteristics of the aquifer reported by Reeder (1972). The bottom of Layer 1 was set at $4 \mathrm{~m}$ below the initial water table and configured as unconfined with an average effective recharge rate (total precipitation minus losses from runoff and evapotranspiration) of $17.7 \mathrm{~cm} \mathrm{yr}^{-1}$ (Puckett et al., 1999). Layer 2 was $4 \mathrm{~m}$ thick and the thickness of layer 3 varied depending on the total thickness of the aquifer. Based on reported hydraulic conductivities of $0.009 \mathrm{~m} \mathrm{~d}^{-1}$ for the underlying till, and 27 to $183 \mathrm{~m} \mathrm{~d}^{-1}$ for the aquifer materials (Reeder, 1972), the bottom of layer 3 was designated as a no-flow boundary as were the northern, eastern, and western edges of the model area; porosity of the sand was assumed to be 0.3 . Although flow may occur across the boundary at the tillsand contact, because of the great disparity in hydraulic conductivities, this component of flow was not considered to be significant. The boundary with Little Pine Lake on the southeastern corner of the area was modeled with constant head cells. The Otter Tail River on the southern side was modeled using the river option with a conductance per unit length of $300 \mathrm{~m}^{2} \mathrm{~d}^{-1} \mathrm{~m}^{-1}$ assuming a vertical hydraulic conductivity of $6 \mathrm{~m} \mathrm{~d}^{-1}$, an average width of $50 \mathrm{~m}$, and a thickness of $1 \mathrm{~m}$. Wetlands were modeled as drains with a conductance per unit length of $83 \mathrm{~m}^{3} \mathrm{~d}^{-1} \mathrm{~m}^{-1}$ assuming a vertical hydraulic conductivity of $0.5 \mathrm{~m} \mathrm{~d}^{-1}$, an average width of $50 \mathrm{~m}$, and a thickness of $0.3 \mathrm{~m}$. Peat hydraulic conductivities used in estimating wetland conductance were based on a range of measurements reported by Siegel and Glaser (1987), Siegel (1988), and Romanowicz et al. (1993). Isotropic conditions of horizontal hydraulic conductivity and a ratio of horizontal to vertical hydraulic conductivity of 5 were assumed.

The ground-water model was calibrated by adjusting the hydraulic conductivity until horizontal hydraulic gradients and predicted water levels reasonably matched those reported in previous investigations and determined by water-level measurements in this 
In Press, Journal of Environmental Quality, Vol. 31, no. 3, 2002.

study (Reeder, 1972). The model-applied hydraulic conductivity of $30 \mathrm{~m} \mathrm{~d}^{-1}$ was at the lower end of the reported range of 27 to $183 \mathrm{~m} \mathrm{~d}^{-1}$ and all factors used in the simulations were within reasonable limits of measured or reported values (Reeder, 1972; Fetter, 1994). The path-line tracking option of MODPATH was used to compute ground-water travel times and delineate flow paths. When initiating particle tracking, particles were placed at the midpoint depth of each well screen (which was the point where we sampled), and the reverse tracking option was used to track the particle back to the position at the water table where it would have originated.

\section{Sample Collection and Analysis}

Sediment samples were collected using a continuous piston core barrel with a polycarbonate sleeve. Selected samples from sites 1 and 3 were sorted into bulk and $<1 \mu \mathrm{m}$ size fractions and analyzed for mineralogy by $\mathrm{x}$-ray diffraction. Samples for these analyses were selected to provide a description of mineralogy at several points across the thickness of the aquifer at these locations. A separate aliquot of each sample was analyzed for total carbon (C), using a Carlo Erba elemental analyzer. A duplicate sample was exposed to hydrochloric acid fumes to remove inorganic $C$ after which organic $\mathrm{C}$ content was measured, and inorganic $\mathrm{C}$ was calculated as the difference between total and organic C (Hedges and Stern, 1984).

Piezometers were sampled up to 7 times during the period from April 1994 to August 1997, using a stainless steel positive displacement pump with Teflon tubing. Sampling procedures are detailed in protocols by Koterba et al. (1995) and Menheer and Brigham (1997) report the specific application of these protocols to this study. Water temperature, specific conductance, and dissolved-oxygen $\left(\mathrm{O}_{2}\right)$ concentration were continuously monitored prior to sample collection. When these measures stabilized, and at least three casing volumes of water had been extracted from the piezometer, sample collection began.

Samples were filtered through a $0.45 \mu \mathrm{m}$ nitrocellulose filter (a silver filter was used for dissolved organic carbon (DOC) samples. Mercuric chloride preservative was added to nutrient samples during 1994 but afterwards, no preservative was added, instead samples were shipped on ice the same day to the U.S. Geological Survey National Water Quality Laboratory in Denver, Colorado for immediate analyses; cation samples were preserved with nitric acid. Alkalinity was determined in the field by incremental titration of filtered samples. Specific conductivity, $\mathrm{pH}$, temperature, and $\mathrm{O}_{2}$ were all measured in a sealed flow-through cell attached to the sample discharge line.

Major cations and silica were analyzed by inductively-coupled plasma spectroscopy, anions by ion chromatography, nutrients by colorometric methods (Fishman and Friedman, 1989; Fishman, 1993; Wershaw et al., 1987) and DOC by persulfate oxidation and infrared spectrometry (Brenton and Arnett, 1992). Equipment blank samples, field blank samples, replicate samples, and spiked samples (Koterba et al., 1995; Menheer and Brigham, 1997) showed a general lack of sampling contamination. 
In Press, Journal of Environmental Quality, Vol. 31, no. 3, 2002.

Sulfide $\left(S^{2-}\right)$ was measured by the methylene blue method (Standard Methods, 1975). Samples were processed immediately using a HACH 2000 portable spectrophotometer with a detection limit of $1.87 \mu \mathrm{mol} \mathrm{L}^{-1} \mathrm{~S}^{2-}$. The geochemical model WATEQ as implemented in NETPATH (Plummer et al., 1994) was used for speciation and calculation of saturation indices. The WATEQ output was then used in the NETPATH program (Plummer et al., 1994) to evaluate various biogeochemical reactions controlling water chemistry along the transect.

Dissolved gases $\left(\mathrm{N}_{2}, \mathrm{Ar}, \mathrm{CO}_{2}, \mathrm{CH}_{4}, \mathrm{O}_{2}\right)$ were analyzed in ground-water samples by gas chromatography after extraction in headspaces of glass samplers (Busenberg et al., 1998). Results were corrected for solubility in sample water at laboratory temperatures and have an error of $\pm 2-4$ percent. Concentrations of $\mathrm{N}_{2}$ and $\mathrm{Ar}$ gases dissolved in water were used to estimate the amount of nitrogen resulting from denitrification (Vogel et al., 1981; Wilson et al., 1990; Bohlke and Denver, 1995; Blicher-Mathiesen et al., 1998). This approach required the assumption that the atmosphere and denitrification were the only sources of $\mathrm{N}_{2}$ in ground water and the atmosphere was the only source of Ar. However, excess air can also become trapped in recharging ground water due to entrainment of air bubbles, and increase dissolved gas concentrations accordingly. This is more of a problem in arid zones where rapid recharge occurs and in fine-grained sediments, but is usually small in coarse sediments and fractures. Where excess air alone affects dissolved gas concentrations, $\mathrm{N}_{2}$ and $\mathrm{Ar}$ increase linearly in a ratio defined by their relative solubilities in water and concentrations in the atmosphere, making it possible to estimate the amount of excess air, which typically is negligible (less than 3 $\mathrm{Cc} \mathrm{kg}^{-1}$ ) and often ignored in studies of this nature (Busenberg et al., 1993; Bohlke and Denver, 1995; Plummer and Busenburg, 1999). However, we made corrections to the excess $\mathrm{N}_{2}$ estimates by subtracting the air-saturated water plus excess air concentrations from the measured concentrations. We estimated the original or reconstructed concentration of $\mathrm{NO}_{3}{ }^{-}$(prior to denitrification) as the sum of measured $\mathrm{NO}_{3}{ }^{-}$and excess $\mathrm{N}_{2}$. Denitrification rates were calculated by dividing the excess $\mathrm{N}_{2}$ gas by sample age.

We also applied the methods presented by Blicher-Mathiesen et al. (1998) to evaluate the potential for degassing of ground water. This method involves comparing the total partial pressures of dissolved gases in each sample to the hydrostatic pressure of the sampled piezometer. Where partial pressures exceed hydrostatic pressure the potential exists for degassing.

Samples for analyses of the chlorofluorocarbons $\mathrm{CFCl}_{3}$ (CFC-11), $\mathrm{CF}_{2} \mathrm{Cl}_{2}(\mathrm{CFC}-12)$, and $\mathrm{C}_{2} \mathrm{~F}_{3} \mathrm{Cl}_{3}$ (CFC-113) were collected using a stainless steel sampling apparatus under an ultra-pure nitrogen atmosphere and were flame sealed in $62 \mathrm{cc}$ borosilicate glass ampoules, preventing atmospheric contamination (Busenberg and Plummer, 1992). Five ampoules were collected at each site, three of which were used for analyses by electron-capture gas chromatography with a detection limit of 0.3 picograms per kilogram of water $\left(\mathrm{pg} \mathrm{kg}^{-1}\right)$ for CFC-11 and CFC-12 and $1.0 \mathrm{pg} \mathrm{kg}^{-1}$ for CFC-113 (Busenberg and Plummer, 1992). CFC's are known to exhibit varying degrees of susceptibility to biodegradation and sorption on organic matter, with CFC12 being least 
In Press, Journal of Environmental Quality, Vol. 31, no. 3, 2002.

affected and CFC11 and CFC113 being the most affected (Cook et al., 1995; Lovely and Woodward, 1992; Plummer and Busenberg, 1999). Consequently, CFC12 was used in most cases for age determinations. Sample ages were assigned based on comparison of CFC equilibrium partial pressures, corrected for recharge temperature, with a chronology of atmospheric partial pressures (Busenberg and Plummer, 1992). Recharge temperatures were estimated in two ways: (1) using Ar concentrations and assuming equilibrium with the atmosphere, and (2) where Ar was not measured based on the average annual temperature (Busenberg and Plummer, 1992). These methods result in a potential uncertainty of about $2^{\circ} \mathrm{C}$ which translates to an age-dating uncertainty of about 1 year prior to 1970, 1-3 years for 1970-1990, and 3 years or more for waters that recharged after 1990. The increasing uncertainty in recent years results from the flattening of the CFC input function due to reductions in CFC usage. Because they typically require some degree of subjective interpretation, CFC age dates are referred to as model or apparent ages and are considered a minimum age (Plummer and Busenberg, 1999).

\section{RESULTS}

\section{Hydrogeology}

Bulk fraction mineralogy (Table 1) was dominated at both sites by five minerals: quartz, plagioclase (probably albite), potassium feldspar, dolomite, and calcite. Quartz was the most abundant except at site OF3, near the contact with the underlying till where plagioclase dominated. Also, potassium feldspar was more common at site OF3 and only appeared in the sample from $12.2 \mathrm{~m}$ deep at site OF11. Dolomite (up to 19 percent) was usually more abundant than calcite (up to 15 percent) although, values in the 1-3 percent range for each were more common. Examination of sediments during drilling revealed that most of the sand was tinted a yellow-red color indicating the presence of iron oxide coatings. These results are also consistent with those reported by Berndt (1987) and Tuccillo et al. (1999) for outwash deposits nearby in the vicinity of Bemidji, Minnesota.

Among the $<1 \mu \mathrm{m}$ size fraction minerals, smectite (probably montmorillonite) was consistently most abundant, followed by illite and kaolinite. Chlorite appeared in samples from site 1 whereas dolomite was in all the samples and calcite was not detected in the $11.6 \mathrm{~m}$ deep sample from site OF3. Feldspars (probably albite and potassium feldspar) were common in all samples and hornblende may have been present in 3 samples.

Total carbon was in consistently greater abundance at site OF1, ranging from 1.11 to 3.17 percent, than at site OF3 where it ranged from 0.06 to 0.89 percent. Interestingly the peak abundance at site OF1 coincided with what had been identified during drilling as a thin black organic layer at $4.6 \mathrm{~m}$ in depth. Inorganic carbon abundance was similar in all samples except for the shallow sample at site OF3 where it was 0.04 percent and the black organic layer at site OF1 where it was 1.71 percent. Organic carbon abundance was variable ranging from 0.01 to 1.45 percent (median=0.15) with the 
In Press, Journal of Environmental Quality, Vol. 31, no. 3, 2002.

largest abundance in the black organic layer at site OF1 and the smallest in the shallow sample from site OF3.

Results of the MODFLOW/MODPATH models indicated that ground water generally flowed north to south, towards the Otter Tail River or Little Pine Lake. Predicted and observed water levels (Table 2) agreed within about $0.6 \mathrm{~m}$ with a root mean square error (RMS) of 0.44 . Simulated flow lines and particle tracking results from the MODPATH simulation (Figure 4) indicated that travel times increased with increasing depth and distance traveled along the transect. Ground water flowing along the deepest and longest flow paths along the transect, from the northern edge of the aquifer to the Otter Tail River, can be expected to take $>70$ years to reach its discharge point in the area of the Otter Tail River (Figure 4). The net result is a well-stratified age distribution within the aquifer (Figure 5).

\section{Dissolved Gases}

Although the median $\mathrm{O}_{2}$ concentration was $8 \mu \mathrm{mol} \mathrm{L}^{-1}$ and values as high as $225 \mu \mathrm{mol}$ $\mathrm{L}^{-1}$ were measured, these were well below the equilibrium value of $373 \mu \mathrm{mol} \mathrm{L}^{-1}$ at $5.6^{\circ} \mathrm{C}$. With the exception of site OF1S, dissolved oxygen concentrations decreased with both increasing age and depth (Table 3 ) suggesting that oxygen was being consumed within the system, presumably to oxidize organic carbon in the outwash sediments. With minor exceptions, samples greater than 10 years old were suboxic $\left(<64 \mu \mathrm{mol} \mathrm{\textrm {L } ^ { - 1 }}\right)$ and appeared to shift from $\mathrm{O}_{2}$ reduction to denitrification as the terminal electron accepting process.

Concentrations of $\mathrm{N}_{2}$ ranged from near equilibrium with the atmosphere $\left(682 \mu \mathrm{mol} \mathrm{L}^{-1}\right.$ at $5.6^{\circ} \mathrm{C}$ ) to $982 \mu \mathrm{mol} \mathrm{L}{ }^{-1}$ with a median of $828 \mu \mathrm{mol} \mathrm{L}^{-1}$ and Ar concentrations ranged from 15.0 to $20.3 \mu \mathrm{mol} \mathrm{L}^{-1}$ (Table 3, Figure 6). The smallest excess $\mathrm{N}_{2}$ concentrations were in waters containing the most $\mathrm{O}_{2}$, whereas the greatest concentrations were in water containing little or no $\mathrm{O}_{2}$ (Table 3), suggesting that denitrification was producing the excess $\mathrm{N}_{2}$. Excess $\mathrm{N}_{2}$ concentrations were as large as $394.4 \mu \mathrm{mol} \mathrm{L}^{-1}$; equivalent to $788.8 \mu \mathrm{mol} \mathrm{L} \mathrm{L}^{-1} \mathrm{NO}_{3}^{-}$, assuming the excess $\mathrm{N}_{2}$ was derived from denitrification. Also, excess $\mathrm{N}_{2}$ concentrations were generally less than $100 \mu \mathrm{mol} \mathrm{L}^{-1}$ in the shallow portions of the aquifer near the water table, increased to the maximum $394.4 \mu \mathrm{mol} \mathrm{L}^{-1}$ at middepths, and then decreased again in the deeper, down-gradient portions of the transect (Figure 7). Denitrification rates calculated from excess $\mathrm{N}_{2}$ gas and sample age, ranged from 0.005 to $0.047 \mathrm{mmol} \mathrm{NO}_{3}{ }^{-} \mathrm{L}^{-1} \mathrm{yr}^{-1}$.

Both $\mathrm{S}^{2-}$ and $\mathrm{CH}_{4}$ concentrations were below detection or negligible in all but the deepest samples (Table 3). $\mathrm{S}^{2-}$ concentrations rose above the detection limit in those samples where $\mathrm{SO}_{4}{ }^{2-}$ concentrations decreased sharply (Table 4), but even in those cases it remained below $1.0 \mu \mathrm{mol} \mathrm{L}^{-1}$ as would be expected given the tendency of $\mathrm{S}^{2-}$ to form iron sulfide precipitates. The presence of both $\mathrm{S}^{2-}$ and $\mathrm{CH}_{4}$ in these deeper portions of the transect indicates the development of relatively strong reducing conditions there. 
In Press, Journal of Environmental Quality, Vol. 31, no. 3, 2002.

\section{CFC Apparent Age Dates}

CFC apparent ages ranged from 5 years in the shallow piezometers to $>50$ years at OF1D and are consistent with the modeling results, given the greater uncertainty of the post-1970 apparent ages. There was a pattern of increasing age with increasing depth along the transect (Figure 5), and a linear relationship $\left(r^{2}=0.759\right)$ between age and depth. The CFC apparent ages and those simulated using the MODPATH model were generally in good agreement $\left(r^{2}=0.835\right)$ although the MODPATH ages tended to be younger (Table 2).

CFC apparent ages reflect the year in which ground water was last in contact with unsaturated zone air (Cook and Solomon, 1997) and previous work at this site has shown that it can take from 0.5 to 1 year for water to percolate through the vadose zone to the water table, and about 2.5 to 4.8 years for water to then reach the sampling zone of the shallow piezometers (Stoner et al., 1997; Puckett et al., 1999). Therefore, a lag of 3 to 6 years between the age of shallow samples and the year in which the precipitation fell is expected. Dissolved gas results indicated that at this site excess air was small and therefore the effects on CFC apparent-age dates were negligible (Plummer and Busenberg, 1999). CFC data for piezometers OF4S and OF3M were much older than could be explained based on model projections. The recharge areas for these sites however, are in an old outwash channel containing wetlands, factors we feel resulted in sorption of the CFC's, leading to the older apparent ages.

\section{Major Ion Chemistry}

Concentrations of $\mathrm{NO}_{3}{ }^{-}$which were as high as $1785 \mu \mathrm{mol} \mathrm{L} \mathrm{L}^{-1}$ with a median of $107 \mu \mathrm{mol}$ $\mathrm{L}^{-1}$, behaved like $\mathrm{O}_{2}$, decreasing with both increasing age and depth (Table 3, Figure 8). This decreasing pattern suggested that once $\mathrm{O}_{2}$ was depleted, $\mathrm{NO}_{3}{ }^{-}$was utilized as the terminal electron acceptor in the oxidation of organic carbon. Samples greater than 30 years old were essentially depleted of $\mathrm{NO}_{3}{ }^{-}$. Concentrations of $\mathrm{NH}_{4}{ }^{+}$reached $50 \mu \mathrm{mol}$ $\mathrm{L}^{-1}$ with a median of $2.1 \mu \mathrm{mol} \mathrm{L} \mathrm{L}^{-1}$. There was a general trend of increasing $\mathrm{NH}_{4}^{+}$ concentration with increasing age and depth. Although the exact source of $\mathrm{NH}_{4}{ }^{+}$was not determined, in other studies of sediments in similar redox environments, $\mathrm{NH}_{4}{ }^{+}$ production has been traced to mineralization of organic nitrogen and not to dissimilatory nitrate reduction (McMahon et al., 1999). Other forms of nitrogen were negligible.

Median DOC concentration was $158 \mu \mathrm{mol} \mathrm{L}^{-1}$ but ranged as high as $375 \mu \mathrm{mol} \mathrm{L} \mathrm{L}^{-1}$, and generally increased with depth. There are several possible explanations for the nearlinear increase in DOC concentrations with depth. First, it may be due to the fact that in earlier years there may not have been sufficient terminal electron acceptors such as $\mathrm{NO}_{3}{ }^{-}$, available to support DOC oxidation. Second, DOC concentrations may have been greater in earlier years. Finally, there is the possibility that DOC concentrations increased over time due to accumulation of the more refractory by-products of organic carbon decomposition. 
Iron concentrations displayed a large range, from below detection to as high as 135 $\mu \mathrm{mol} \mathrm{L^{-1 }}$. Such relatively large concentrations of dissolved iron suggests that the predominant terminal electron accepting process had changed from reduction of $\mathrm{O}_{2}$, $\mathrm{NO}_{3}{ }^{-}$, and manganese oxides to iron oxide reduction. Furthermore, these concentrations are consistent with results from similar sediments nearby in Bemidji, Minnesota that contain sufficient coatings of iron oxides on quartz and feldspar grains to generate $\mathrm{Fe}^{2+}$ concentrations of $35000 \mu \mathrm{mol} \mathrm{L}^{-1}$ if reduced simultaneously (Tuccillo et al., 1999). Manganese concentrations reached as much as $11 \mu \mathrm{mol} \mathrm{L}^{-1}$ and typically peaked when most $\mathrm{NO}_{3}{ }^{-}$had been consumed and $\mathrm{Fe}^{2+}$ was increasing. This pattern agrees with the reported redox sequence where manganese oxide reduction occurs at pe levels after denitrification and before iron oxide reduction (Stumm and Morgan, 1981).

$\mathrm{Ca}^{2+}, \mathrm{Mg}^{2+}$, and $\mathrm{HCO}_{3}{ }^{-}$were the dominant dissolved species, which is consistent with what is known of the outwash mineralogy and agricultural applications. Farmers in the area typically apply 6.7-8.9 metric tons $\mathrm{ha}^{-1} \mathrm{yr}^{-1}$ of limestone containing both calcite and dolomite (Denzel Cooper, University of Minnesota Extension Service, oral communication, 1996). Infiltrating ground waters would therefore be expected to develop a carbonate signature as a result of dissolution of these carbonates. The ratio of $\mathrm{Ca}^{2+}$ to $\mathrm{Mg}^{2+}$ was approximately 2:1 which suggests dissolution of calcite and dolomite in roughly equal amounts. $\mathrm{HCO}_{3}$ concentrations generally increased with increasing depth in the aquifer.

Chloride $\left(\mathrm{Cl}^{-}\right)$and sulfate $\left(\mathrm{SO}_{4}{ }^{2-}\right)$ concentrations ranged as high as 2003 and $1103 \mu \mathrm{mol}$ $\mathrm{L}^{-1}$, respectively. Chloride commonly occurs in fertilizer as potassium chloride $(\mathrm{KCl})$ and is a common contaminant associated with agricultural areas. With respect to sulfur, there is little available in the outwash sediments; therefore, it is commonly supplied as an agricultural supplement either as gypsum $\left(\mathrm{CaSO}_{4} \cdot 2 \mathrm{H}_{2} \mathrm{O}\right)$ or in more recent years as ammonium sulfate $\left(\left(\mathrm{NH}_{4}\right)_{2} \mathrm{SO}_{4}\right)$ at rates of $28-336 \mathrm{~kg} \mathrm{~S}^{-1}$ (Denzel Cooper, University of Minnesota Extension Service, oral communication, 1996). Typically, the larger amount is applied once in a 6-year rotation as a starter for alfalfa and the smaller amount is applied as a starter for corn. At the estimated ground-water recharge rate of $17.7 \mathrm{~cm} \mathrm{yr}^{-1}$ (Cowdery, 1997; Puckett et al., 1999), these application rates would result in a spatially average concentration of $495-5934 \mu \mathrm{mol} \mathrm{SO}_{4}{ }^{2-} \mathrm{L}^{-1}$ and therefore can easily account for the observed concentrations. The distributions of both $\mathrm{Cl}^{-}$and $\mathrm{SO}_{4}{ }^{2-}$ (Figure $9 a, b)$ reflect the most intensive areas of agriculture along the transect, and the lowest concentrations are generally found in the deeper, down-gradient portions of the transect. These lower concentrations also are associated with the oldest ground waters, which is to be expected since less fertilizer was used at that time and some $\mathrm{SO}_{4}{ }^{2-}$ reduction occurred as well.

\section{Biogeochemical Modeling}

The NETPATH model (Plummer et al., 1994) employs a reverse-reaction process that predicts the net amount of various minerals or gas phases that must enter or leave 
In Press, Journal of Environmental Quality, Vol. 31, no. 3, 2002.

solution in order to explain the observed changes in water chemistry between two points on a flow path. In this case, we focused on the reactions in the upper portion of the aquifer where the ground water becomes depleted in $\mathrm{O}_{2}$ and $\mathrm{NO}_{3}{ }^{-}$accompanied by increases in $\mathrm{HCO}_{3}^{-}$. We used water chemistry for the piezometers at sites OF3S and OF1B for the NETPATH runs since these sample points lie roughly along the same flow path (Figure 4).

Our focus in the model was on the reactions responsible for $\mathrm{O}_{2}$ and $\mathrm{NO}_{3}{ }^{-}$losses, and increases in $\mathrm{C}, \mathrm{Ca}^{2+}$, and $\mathrm{Mg}^{2+}$, including deducing the electron donors in the redox reactions. In addition to the calcite $\left(\mathrm{CaCO}_{3}\right)$, dolomite $\left(\mathrm{CaMg}\left(\mathrm{CO}_{3}\right)_{2}\right)$, and organic matter, that occur naturally in the soil, agricultural inputs at the site include calcite, dolomite, potassium (as $\mathrm{KCl}$ ), nitrogen (as $\mathrm{NO}_{3}{ }^{-}$and $\mathrm{NH}_{4}{ }^{+}$), and sulfur (as $\mathrm{CaSO}_{4} \cdot 2 \mathrm{H}_{2} \mathrm{O}$ or $\left.\left(\mathrm{NH}_{4}\right)_{2} \mathrm{SO} 4\right)$. Accordingly, $\mathrm{C}, \mathrm{Ca}, \mathrm{Mg}, \mathrm{K}, \mathrm{Na}, \mathrm{N}, \mathrm{S}, \mathrm{Cl}$ and redox state were among the constraints in the model and the phases included nitrogen gas $\left(\mathrm{N}_{2}\right)$, organic matter $\left(\mathrm{CH}_{2} \mathrm{O}\right)$, calcite, dolomite, gypsum $\left(\mathrm{CaSO}_{4} \cdot 2 \mathrm{H}_{2} \mathrm{O}\right)$, and potassium chloride $(\mathrm{KCl})$. We also modeled ion exchange of both $\mathrm{K}$ and $\mathrm{Na}$ with $\mathrm{Ca}$ and $\mathrm{Mg}$. The phases were chosen on the basis of mineralogy and the saturation indices calculated in WATEQ.

Four NETPATH models (Table 5) were found that fit the constraints, phases, saturation indices and mineralogy. In all the models organic matter was oxidized and $\mathrm{N}_{2}$ left solution, small amounts of $\mathrm{KCl}$ and gypsum were dissolved, and $\mathrm{Na}$ exchanged for $\mathrm{Ca}$ and $\mathrm{Mg}$. Calcite and(or) dolomite dissolved in all of the models, and in those models where one phase or the other was not selected, $\mathrm{K}$ exchange for $\mathrm{Ca}$ or $\mathrm{Mg}$ balanced the reaction. Because we know that both calcite and dolomite are applied in the area, models 1 and 2 (Table 5) seem most realistic.

These results indicate that in this portion of the aquifer $\mathrm{O}_{2}$ and $\mathrm{NO}_{3}{ }^{-}$were being reduced by oxidation of organic matter with about two thirds (66.5 percent) of the net increase in carbon being generated in the process. $\mathrm{O}_{2}$ loss accounted for about 8 percent of the oxidation of organic carbon while $\mathrm{NO}_{3}{ }^{-}$reduction accounted for the other 92 percent. Dissolution of carbonates accounted for about a third (33.5 percent) of the net increase in carbon. The net loss of $\mathrm{N}_{2}$ most likely was required in order to balance differences in the amount of nitrogen applied in fertilizer at the time of recharge. This was not surprising given the approximate doubling in the amount of fertilizer nitrogen applied in Otter Tail county during the 16-20 year time period between the recharge dates of the two samples (Figure 2). 
In Press, Journal of Environmental Quality, Vol. 31, no. 3, 2002.

\section{DISCUSSION}

\section{Redox Processes}

Analytical results (Table 3, 4) show that the upper 3-4 $\mathrm{m}$ ( $<10$ years old) of the saturated zone were well below the equilibrium concentration for $\mathrm{O}_{2}\left(373 \mu \mathrm{mol} \mathrm{L} \mathrm{L}^{-1}\right)$. However, this zone was not anoxic, indicating that it was a zone where $\mathrm{O}_{2}$ reduction was occurring (Figure 10). Below the zone of $\mathrm{O}_{2}$ reduction was another 3-4 $\mathrm{m}$ (10-20 years old) thick zone essentially depleted of $\mathrm{O}_{2}$, where $\mathrm{NO}_{3}{ }^{-}$reduction was occurring with essentially complete denitrification at its base. Most of the remainder of the outwash sediments comprised a zone of iron oxide reduction ranging from 20 to 50 years in age, with a small zone of $\mathrm{SO}_{4}{ }^{2-}$ reduction and $\mathrm{CH}_{4}$ production in the sediments containing ground water $>50$ years in age (Figure 10). The loss of both $\mathrm{O}_{2}$ and $\mathrm{NO}_{3}{ }^{-}$in the shallow portions of the aquifer (Table 3,4), accompanied by the production of large amounts of $\mathrm{HCO}_{3}{ }^{-}$(Table 4) and excess $\mathrm{N}_{2}$ (Figure 7) indicate that oxidation of organic carbon with $\mathrm{NO}_{3}{ }^{-}$as the electron acceptor was occurring and this is supported by the NETPATH model results. At equilibrium, dissolved $\mathrm{O}_{2}$ would be $373 \mu \mathrm{mol} \mathrm{L}^{-1}$ and therefore would place a demand of 1492 electron equivalents (Postma et al., 1991). The introduction of $463 \mu \mathrm{mol} \mathrm{NO}{ }_{3}^{-} \mathrm{L}^{-1}$ (the median concentration of $\mathrm{NO}_{3}{ }^{-}$in the shallow aquifer) places an additional demand of 2315 electron equivalents. The combined electron demand is about 2.5 times that of $\mathrm{O}_{2}$ alone, increasing the amount of $\mathrm{C}$ oxidized. As organic $\mathrm{C}$ continues to be oxidized in the shallow sediments we can expect to see the depths to which $\mathrm{NO}_{3}{ }^{-}$persists increase, however the rate of downward movement can be expected to take decades. Similar conclusions were reached by Robertson et al. (1996) for an aquifer in southern Ontario where reduced sulfur compounds served as the electron donor for autotrophic denitrification.

Together, these results indicate that the biogeochemistry of the shallow ground-water system is dominated by facultative anaerobes that initially derive energy from the oxidation of organic carbon in the sediments, and once concentrations of $\mathrm{O}_{2}$ are limiting, switch to denitrification as the terminal electron accepting process for carbon oxidation. Deeper in the aquifer, iron-reducing bacteria become favored, followed by $\mathrm{SO}_{4}{ }^{2-}$ reducers and then methanogens, creating the pattern depicted in Figure 10. This pattern follows the predicted redox sequence based on thermodynamics of the reactions involved and microbial energy demands (Stumm and Morgan, 1981; Chapelle, 1993; Chapelle et al., 1995).

The redox zonation has implications on the potential transport and fate of $\mathrm{NO}_{3}{ }^{-}$entering the aquifer. Specifically, $\mathrm{NO}_{3}{ }^{-}$is thermodynamically and biologically unstable below a depth of about 3-4 $\mathrm{m}$ below the water table. Because the denitrification process is dependent on organic $\mathrm{C}$ as an electron donor, the future ability of this aquifer to continue removing $\mathrm{NO}_{3}$ is dependent on the availability of reactive organic $\mathrm{C}$. It is generally accepted that leaching from soil horizons is the primary source of dissolved organic carbon to shallow flow systems (Chapelle, 1993). Korom (1992) has stated that given the stoichiometry of equation 2 , on a molar basis there must be 25 percent more dissolved organic carbon than $\mathrm{NO}_{3}{ }^{-}$, in order for denitrification to proceed to completion. 
In Press, Journal of Environmental Quality, Vol. 31, no. 3, 2002.

However, this assumption ignores another widely accepted fact that buried organic matter may also provide the organic carbon required for denitrification (Chapelle, 1993; Appelo and Postma, 1996). Also, because this buried organic matter often is refractory, and may limit microbial processes, its reactivity controls the extent of denitrification (Chapelle, 1993; Appelo and Postma, 1996).

Sediment organic carbon content was variable but ranged from $0.01-1.45$ percent with a median of 0.15 percent. Applying an analysis similar to that of Trudell et al. (1986), and assuming a porosity of 0.3 and a particle density of $2.65 \mathrm{~g} \mathrm{~cm}^{-3}$, results in an estimate of $52-7471 \mathrm{mmol}$ organic $\mathrm{C}$ with a median of $773 \mathrm{mmol} \mathrm{C}$, in each $3.3 \mathrm{~L}$ volume of sediment. Based on the stoichiometry of denitrification in equation 2 , this would translate to the ability to reduce $42-5977 \mathrm{mmol} \mathrm{NO}_{3}{ }^{-}$in each liter of water in contact with each $3.3 \mathrm{~L}$ volume of sediment. Given that the maximum concentration of $\mathrm{NO}_{3}{ }^{-}$ measured along the transect was $1785 \mu \mathrm{mol} \mathrm{L}^{-1}$, it is obvious that even the relatively small amounts of organic carbon present in the aquifer are adequate to explain the redox conditions. Grischek et al. (1998) reached similar conclusions in their study of a sand and gravel aquifer in Germany that had received organic carbon from infiltrating Elbe River waters.

At the smallest organic $\mathrm{C}$ concentration ( 0.01 percent) and the median $\mathrm{NO}_{3}{ }^{-}$ concentration at the water table $\left(436 \mu \mathrm{mol} \mathrm{L}^{-1}\right)$ all of the $\mathrm{O}_{2}\left(373 \mu \mathrm{mol} \mathrm{L}^{-1}\right.$ assuming equilibrium with the atmosphere) and $\mathrm{NO}_{3}{ }^{-}$originally present should be consumed in the upper $2 \mathrm{~m}$ of the saturated zone. That this is not occurring suggests that either the organic $\mathrm{C}$ is not readily accessible for $\mathrm{O}_{2}$ reduction and denitrification, or that other biological, thermodynamic, and (or) kinetic constraints exist with the result that most of the aquifer appears to be carbon limited, resulting in slow denitrification rates.

\section{Denitrification Rates}

Denitrification rates are typically measured in controlled incubations under laboratory conditions; however, these rates are typically greater than those determined by in-situ studies, or even tracer studies and all appear to overestimate nitrate losses under natural conditions. Smith et al. (1996) attempted to correct for these overestimates by injecting bromide as a tracer along with nitrate and then monitoring along the flow path for denitrification products. The rates calculated from their experiments were less than slurry and soil core incubations done with the same material but were of the same order of magnitude. Other in-situ studies (Trudell et al., 1986; Gillham et al., 1990; Tesoriero et al., 2000) typically have produced rates an order of magnitude greater than those of Smith et al. (1996). Another method is to measure the production of excess $\mathrm{N}_{2}$ or $\mathrm{N}_{2} \mathrm{O}$ gas generated from denitrification and estimate a denitrification rate based on sample age (Vogel et al., 1981; Smith et al., 1996; Tesoriero et al., 2000). Rates based on the excess $\mathrm{N}_{2}$ method may be an order of magnitude lower than those based on tracer tests.

Denitrification rates based on excess $\mathrm{N}_{2}$ gas and sample age measured in this study, ranged from 0.005 to $0.047 \mathrm{mmol} \mathrm{NO}_{3}^{-} \mathrm{L}^{-1} \mathrm{yr}^{-1}$. These rates are orders of magnitude 
In Press, Journal of Environmental Quality, Vol. 31, no. 3, 2002.

lower than what has typically been measured in laboratory and in-situ incubations (Table 6) but are comparable to those from other field-based studies in sand and gravel aquifers (Bohlke and Denver, 1995; Smith et al., 1996; Tesoriero et al., 2000). The slowest denitrification rates (Table 6) were from Vogel et al. (1981), who reported a loss of $1.5 \mathrm{mmol} \mathrm{NO}_{3}{ }^{-}$over a period of about 14000 years for a carbon limited system in the Kalahari Desert. Rates reported by Tesoriero et al. (2000) overlap those reported here and were dependent on both carbon and pyrite weathering providing $\mathrm{Fe}^{2+}$ as the electron donor. The somewhat faster rates reported by Smith et al. (1996) were measured in an aquifer contaminated with treated sewage, but denitrification was still carbon limited. These studies indicate that rates measured under field conditions are generally much lower than either laboratory or isolated in-situ incubations and we theorize that they reflect the natural variability of conditions favorable for denitrification. Because there are no additions or modifications to the natural system (other than well installation and sampling) these rates may come closest to actual denitrification rates. Rates derived in this manner therefore are likely better measures of natural denitrification rates and would provide more accurate predictions of $\mathrm{NO}_{3}{ }^{-}$transport and fate.

\section{Age and Land-Use Relations}

The distribution of the reconstructed concentrations (Figure 11) and ground-water age dates (Figure 5) clearly show that $\mathrm{NO}_{3}{ }^{-}$has been increasing in the study area since the 1940 s, and concentrations have nearly doubled in some portions of the aquifer since the mid-1960s. Most importantly, since the late 1960's, reconstructed $\mathrm{NO}_{3}{ }^{-}$ concentrations at many sites have been near or exceeded the maximum contaminant level (MCL) of $714 \mu \mathrm{mol} \mathrm{NO}{ }_{3}^{-} \mathrm{L}^{-1}\left(10 \mathrm{mg} \mathrm{L}^{-1} \mathrm{NO}_{3}-\mathrm{N}\right)$ set by the U.S. Environmental Protection Agency (1996). Puckett et al. (1999) showed that most of the nitrogen reaching the water table in the study area originated as fertilizer, and this increase in $\mathrm{NO}_{3}{ }^{-}$concentrations over time corresponds to a similar increase in the use of fertilizer nitrogen in the study area, particularly after the late-1960s (Figure 2). These results support our hypothesis that changes in concentrations of $\mathrm{NO}_{3}{ }^{-}$are a function of changes in agricultural practices over time and, therefore the age of water sampled along the transect.

Although limited, there is growing evidence that increased fertilizer use since the 1960s has led to aquifer contamination. Bohlke and Denver (1995) reported a similar increase in $\mathrm{NO}_{3}{ }^{-}$in ground water in sandy unconsolidated sediments of the Atlantic Coastal Plain of Maryland beginning in the late 1960 s or early 1970 s. Johnston et al. (1998) noted an increase from $<178 \mu \mathrm{mol} \mathrm{NO}_{3}{ }^{-} \mathrm{L}^{-1}$ to more than $714 \mu \mathrm{mol} \mathrm{NO}_{3}{ }^{-} \mathrm{L}^{-1}$ since 1970 in a sand and gravel outwash aquifer in southern Ontario, Canada. However, because Johnston et al. (1998) did not measure dissolved $\mathrm{N}_{2}$ in the deeper, older ground water; it is impossible to definitively say whether or not the lower concentrations there were due to lower fertilizer usage in earlier years or were the result of denitrification. It is significant that in both these studies, widespread $\mathrm{NO}_{3}{ }^{-}$contamination of the aquifers has occurred, and in the Maryland study area, $\mathrm{NO}_{3}{ }^{-}$-contaminated ground water was discharged to 
In Press, Journal of Environmental Quality, Vol. 31, no. 3, 2002.

streams. On the other hand, in the Otter Tail aquifer denitrification has removed most $\mathrm{NO}_{3}{ }^{-}$in all but the upper few meters of the saturated zone.

\section{CONCLUSIONS}

The results of this study demonstrate the importance of developing a complete understanding of the hydrogeologic and biogeochemical processes involved when evaluating the fate of ground-water contaminants. Age-dating techniques combined with sampling along flow paths, allow us to develop a chronology of the change in contaminant concentrations over time and to relate those changes to historical changes in land-use and management practices. Because residence times on the order of 50 years or more are not unusual, there may be adequate time in many aquifers for even slow biogeochemical process to modify original contaminant concentrations. These modifications require us to monitor not only the original contaminant concentrations but the breakdown products as well in order to understand the processes involved. The final result however, is a more comprehensive appreciation of the biogeochemical processes involved than could be gained from a one- or two-dimensional sampling approach. More studies are required in order to document the spatial extent of the role of denitrification in removing $\mathrm{NO}_{3}{ }^{-}$from contaminated aquifers; it is likely however that many other aquifers in settings similar to the Otter Tail aquifer contain sufficient organic carbon to support denitrification and natural bioremediation.

\section{ACKNOWLEDGEMENTS}

This study was conducted as part of the U.S. Geological Survey National Water Quality Assessment Program (NAWQA) and benefited from the assistance of Jeffrey Stoner, Lan Tornes, Mark Brigham, and David Lorenz. We particularly appreciated the technical reviews of Timothy Spruill, James LaBaugh, Jeffrey Stoner, and two anonymous reviewers. The use of trade names in this paper is for identification purposes only and does not constitute endorsement by the U.S. Geological Survey. 
In Press, Journal of Environmental Quality, Vol. 31, no. 3, 2002.

\section{REFERENCES}

Addy, K.L., A.J. Gold, P.M. Groffman, and P.A. Jacinthe, 1999. Ground water nitrate removal in subsoil of forested and mowed riparian buffer zones. J. Environ. Qual. 28:962-970.

Appelo, C.A.J., and D. Postma, 1996. Geochemistry, groundwater and pollution. A.A. Balkema, Rotterdam. p. 275

Berndt, M.P., 1987, Metal partitioning in a sand and gravel aquifer contaminated by crude petroleum, Bemidji, Minnesota, Master's Thesis. Syracuse University.

Blicher-Mathiesen, G., G.W. McCarty, and L.P. Nielsen, 1998. Denitrification and degassing in ground water estimated from dinitrogen and argon. J. Hydrol. 208: 16-24.

Bohlke, J.K. and J.M. Denver. 1995, Combined use of ground water dating, chemical, and isotopic analyses to resolve the history and fate of nitrate contamination in two agricultural watersheds, Atlantic coastal plain, Maryland. Water Resour. Res., 31:2319-2339.

Bottcher, J., O. Strebel, S. Voerklius, and H.L. Schmidt, 1990. Using isotope fractionation of nitrate-nitrogen and nitrate-oxygen for evaluation of microbial denitrification in a sandy aquifer. J. Hydrol. 114:413-324.

Brenton, R.W., and T.L. Arnett, 1992. Determination of dissolved organic carbon by UVpromoted persulfate oxidation and infrared spectrometry. U.S. Geological Survey Open-File Report 92-480. 12 p.

Busenberg E., and L.N. Plummer, 1992. Use of chlorofluorocarbons $\left(\mathrm{CCl}_{3} \mathrm{~F}\right.$ and $\left.\mathrm{CCl}_{2} \mathrm{~F}_{2}\right)$ as hydrologic tracers and age-dating tools: The alluvium and terrace system of central Oklahoma. Water Resour. Res. 28:2257-2283.

Busenberg, E., E.P. Weeks, L.N. Plummer, and R.C. Bartholomay, 1993. Age dating ground water by use of chlorofluorocarbons $\left(\mathrm{CCl}_{3} \mathrm{~F}\right.$ and $\left.\mathrm{CCl}_{2} \mathrm{~F}_{2}\right)$, and distribution of chlorofluorocarbons in the unsaturated zone, Snake River Plain Aquifer, Idaho National Engineering Laboratory, Idaho. U.S. Geological Survey WaterResources Investigations Report 93-4054. 47 p.

Busenberg E., L.N. Plummer, R,C, Bartholomay, and J.E. Wayland, 1998. Chlorofluorocarbons, sulfur hexafluoride, and dissolved permanent gases in ground water from selected sites in and near the Idaho National Engineering and Environmental Laboratory, Idaho, 1994-97. U.S. Geological Survey Open-File Report 98-274. $72 \mathrm{p}$.

Chapelle, F.H., 1993. Ground-water microbiology and geochemistry. John Wiley and Sons. New York. 424 p.

Chapelle, F.H., P.B. McMahon, N.M. Dubrovsky, R.F. Fujii, E.T. Oaksford, and D.A. Vroblevsky, 1995. Deducing the distribution of terminal electron-accepting processes in hydrologically diverse ground water systems. Water Resour. Res. 31:359-371.

Cook, P.G., and D.K. Solomon, 1997. The transport of atmospheric trace gases to the water table: Implications for ground water dating with chlorofluorocatbons and Krypton-85. Water Resour. Res. 31:263-434.

Cook, P.G., D.K. Solomon, L.N. Plummer, E. Busenberg, and S.L. Schiff, 1995. Chlorofluorocarbons as tracers of ground water transport processes in a shallow, silty and aquifer. Water Resour. Res. 31:425-434. 
In Press, Journal of Environmental Quality, Vol. 31, no. 3, 2002.

Cowdery, T.K., 1997. Shallow ground-water quality beneath cropland in the Red River of the North Basin, Minnesota and North Dakota, 1993-95. U.S. Geological Survey Water-Resources Investigations Report 97-4001. 52 p.

Fetter, C.W., 1994. Applied Hydrology. 3rd ed. Prentice-Hall, Inc. Upper Saddle River, New Jersey. p. 321-325.

Fishman, M.J., 1993. Methods of analysis by the U.S. Geological Survey National Water Quality Laboratory-Determination of inorganic and organic constituents in water and fluvial sediments, U.S. Geological Survey Open-File Report 93-125. $217 \mathrm{p}$.

Fishman, M.J., and L.C. Friedman, 1989. Methods for determination of inorganic substances in water and fluvial sediments. U.S. Geological Survey Techniques of Water-Resources Investigations. book 5, chapter A1, 545 pp. U.S. Gov. Print. Off. Washington, D.C.

Gillham, R.W., and J.A. Cherry, 1978. Field evidence of denitrification in shallow ground water flow systems. Water Pollution Research in Canada 13:53-71.

Gillham, R.W., R.C. Starr, and D.J. Miller, 1990. A device for in situ determination of geochemical transport parameters, 2. Biochemical reactions. Ground Water 28:858-862.

Gold, A.J., P.A. Jacinthe, P.M. Groffman, W.R. Wright, and R.H. Puffer, 1998. Patchiness in ground water nitrate removal in a riparian forest. J. Environ. Qual. 27:146-155.

Goldstein, B.S., 1985. Stratigraphy, sedimentology, and Late-Quaternary history of the Wadena Drumlin Region, central Minnesota. Ph.D. Thesis. Department of Geology and Geophysics. University of Minnesota-Minneapolis. 216 p.

Grischek, T., K.M. Hiscock, T. Metschies, P.F. Dennis, and W. Nestler, 1998. Factors affecting denitrification during infiltration of river water into a sand and gravel aquifer in Saxony, Germany. Water Research 32:450-460.

Harbaugh A.W., and M.G. McDonald, 1996. User's documentation for MODFLOW-96, an update to the U.S. Geological Survey modular finite-difference ground-water flow model. U.S. Geological Survey Open-File Report 96-485. 56 p.

Heaton, T.H.E., and J.C. Vogel, 1981. "Excess air" in ground water. J. Hydrol. 50:201216.

Hedges, J.L., and J.H. Stern, 1984. Carbon and nitrogen determinations of carbonatecontaining solids. Limnology and Oceanography 29:657-663.

Jacinthe, P.A., P.M. Groffman, A.J. Gold, and A. Mosier, 1998. Patchiness in microbial nitrogen transformations in ground water in a riparian forest. J. Environ. Qual. 27:156-164.

Johnston, C.T., P.G. Cook, S.K. Frape, L.N. Plummer, E. Busenberg, and R.J. Blackport, 1998. Ground water age and nitrate distribution within a glacial aquifer beneath a thick unsaturated zone. Ground Water 36:171-180.

Kolle, W., P. Werner, O. Strebel, and J. Bottcher, 1983. Denitrifikation in einem reduzierenden grundwasserleiter. Vom Wasser. 61:125-147.

Korom, S.F., 1992. Natural denitrification in the saturated zone: A review. Water Resour. Res. 28:1657-1668.

Koterba, M.T., F.D. Wilde, and W.W. Lapham, 1995. Ground-water data-collection protocols and procedures for the National Water-Quality Assessment Program- 
In Press, Journal of Environmental Quality, Vol. 31, no. 3, 2002.

Collection and documentation of water-quality samples and related data. U.S. Geological Survey Open-File Report 95-399. 113 p.

Lovely, D.R., and J.C. Woodward, 1992. Consumption of freons CFC-11 and CFC-12 by anaerobic sediments and soils. Environ. Sci. Technol. 26:925-929.

McDonald, M.G., and A.W. Harbaugh, 1988. A modular three-dimensional finitedifference ground-water model, U.S. Geological Survey Techniques of WaterResources Investigations Book 6, chapter A1. U.S. Gov. Print. Off. Washington, D.C.

McMahon, P.B., J.K. Bohlke, and B.W. Bruce, 1999. Denitrification in marine shales in northeastern Colorado, USA. Water Resour. Res. 35:1629-1642.

Menheer, M.A., and M.E. Brigham, 1997. National Water-Quality Assessment Program-Ground-water sampling methods and quality control for the Red River of the North Basin, 1993-1995. U.S. Geological Survey Water-Resources Investigations Report 96-4317. $34 \mathrm{p}$.

Modica, E., H.T. Buxton, and L.N. Plummer, 1998. Evaluating the source and residence times of ground water seepage to streams, New Jersey Coastal Plain. Water Resour. Res. 34:2792-2810.

Morris, J.T., G.J. Whiting, and F.H. Chapelle, 1988. Potential denitrification rates in deep sediments from the southeastern coastal plain. Environ. Sci. Technol. 22:832-836.

Plummer, L.N., and E. Busenberg, 1999. Chlorofluorocarbons, In Cook, P. and A. Herczeg eds., Environmental tracers in subsurface hydrology, Chapter 15, Kluwer Academic Press, p. 441-478.

Plummer, L.N., E.C. Prestemon, and D.L. Parkhurst, 1994. An interactive code (NETPATH) for modeling NET geochemical reactions along a flow PATH, version 2.0. U.S. Geological Survey Water-Resources Investigations Report 944169. $130 \mathrm{p}$.

Pollock, D.W., 1989. Documentation of computer programs to complete and display pathlines using results from the U.S. Geological Survey modular threedimensional finite-difference ground-water model, U.S. Geological Survey OpenFile Report 89-381. $81 \mathrm{p}$.

Postma, D., C. Boesen, H. Kristiansen, and F. Larsen, 1991. Nitrate reduction in an unconfined aquifer: water chemistry, reduction processes, and geochemical modeling. Water Resour. Res. 27:2027-2045.

Puckett, L.J., 1995. Identifying the major sources of nutrient water pollution. Environ. Sci. Technol. 29:408A-414A.

Puckett, L.J., T.K. Cowdery, D.L. Lorenz, and J.D. Stoner, 1999. Estimation of nitrate contamination of an agro-ecosystem aquifer using a nitrogen mass-balance budget. J. Environ. Qual. 28:2015-2025.

Puckett, L.J., T.K. Cowdery, P.B. McMahon, L.H. Tornes and J.D. Stoner, 2001. Using chemical, hydrologic, and age dating analysis to delineate redox processes and flow paths in the riparian zone of a glacial outwash aquifer-stream system, in review.

Reeder, H.O., 1972. Availability of ground water for irrigation from glacial outwash in the Perham area, Otter Tail County, Minnesota. U.S. Geological Survey WaterSupply Paper 2003. 45 p. 3 plates. 
In Press, Journal of Environmental Quality, Vol. 31, no. 3, 2002.

Robertson, W.D., B.M. Russell, and J.A. Cherry, 1996. Attenuation of nitrate in aquitard sediments of southern Ontario. J. Hydrol. 180:267-281.

Romanowicz, E.A., D.I. Siegel, and P.H. Glaser, 1993. Hydraulic reversals and episodic methane emissions during drought cycles in mires. Geology 21:231-234.

Smith, R.L., B.L. Howes, and J.H. Duff, 1991. Denitrification in nitrate-contaminated ground water: Occurrence in steep vertical geochemical gradients. Geochim. Cosmochim. Acta 55:1815-1825.

Smith, R.L., S.P. Garabedian, and M.H. Brooks, 1996. Comparison of denitrification activity measurements in ground water using cores and natural gradient tracer tests. Environ. Sci. Technol. 30:3448-3456.

Spalding, R.F., and J.D. Parrott, 1994. Shallow ground water denitrification. The Science of the Total Environment 141:17-25.

Standard Methods, 1975. Standard Methods for the Examination of Water and Wastewater. $14^{\text {th }}$ Edition. American Public Health Association. Washington, D.C. $1193 \mathrm{p}$.

Starr, R.C., and R.W. Gillham, 1993. Denitrification and organic carbon availability in two aquifers. Ground Water 31:934-947.

Stoner, J.D., D.L. Lorenz, G.J. Wiche, and R.M. Goldstein, 1993. Red River of the North Basin, Minnesota, North Dakota, and South Dakota. Water Resources Bulletin 29:575-615.

Stoner, J.D, T.K. Cowdery, and L.J. Puckett, 1997. Ground-water age dating and other tools used to assess land-use effects on water quality. U.S. Geological Survey Water-Resources Investigations Report 97-4150. 6 p.

Strebel, O., J. Bottcher, and W. Kolle, 1985. Stoffbilanzen im grundwasser eines einzugsgebeites als hilfsmittel bei klarung und prognose von grundwasserqualitatsproblemen (Beispiel Fuhrberger Feld). Z. Dtsch. Geol. Ges. 136:533-541.

Stumm, W., and J.J. Morgan, 1981. Aquatic Chemistry. John Wiley \& Sons. New York. $780 \mathrm{p}$.

Tesoriero, A.J., H. Liebscher, and S.E. Cox, 2000. The mechanism and rate of denitrification in an agricultural watershed: electron and mass balance along ground water flow paths. Water Resour. Res. 36:1545-1559.

Trudell, M.R., R.W.Gillham, and J.A. Cherry, 1986. An in-situ study of the occurrence and rate of denitrification in a shallow unconfined sand aquifer. J. Hydrol. 83:251268.

Tucillo, M.E., I.M. Cozarelli, and J.S. Herman, 1999. Iron reduction in the sediments of a hydrocarbon-contaminated aquifer. Applied Geochemistry 14:655-667.

U.S. Environmental Protection Agency, 1996. Drinking water regulations and health advisories. U.S. Environmental Protection Agency. 11 p.

Van Beek, C.G.E.M., H. boukes, D. van Rijsbergen, and R. Straatman, 1988. The threat of the Netherlands waterworks by nitrate in the abstracted ground water, as demonstrated on the well field Vierlingsbeek. Water Supply 6:313-318.

Vogel, J.C., A.S.Talma, and T.H.E. Heaton, 1981. Gaseous nitrogen as evidence for denitrification in ground water. J. Hydrol. 50:191-200.

Wershaw, R.L., M.J. Fishman, R.R. Grabbe, and L.E. Lowe, 1987. Methods for the determination of organic substances in water and fluvial sediments. U.S. Geological Survey Techniques of Water-Resources Investigations, book 5, 
In Press, Journal of Environmental Quality, Vol. 31, no. 3, 2002.

chapter A3. U.S. Gov. Print. Off. Washington, D.C.

Wilson, G.B., J.N. Andrews, and A.H. Bath, 1990. Dissolved gas evidence for denitrification in the Lincolnshire limestone ground waters, eastern England. J. Hydrol. 113:51-60.

Winter, T.C., and M.K. Woo, 1990. Hydrology of lakes and wetlands. In Wolman, M.G., and H.C. Riggs, (eds.). Surface Water Hydrology: The Geology of North America, volume O-1. Geological Society of America. Boulder, CO. p. 159-187. 1 plate.

Wright, Jr., H.E., 1972. Quaternary history of Minnesota. p. 540-543. In Sims, P.K. and G.B. Morey, (eds.). Minnesota-A Centennial Volume. Minnesota Geological Survey. St. Paul. Minnesota. 


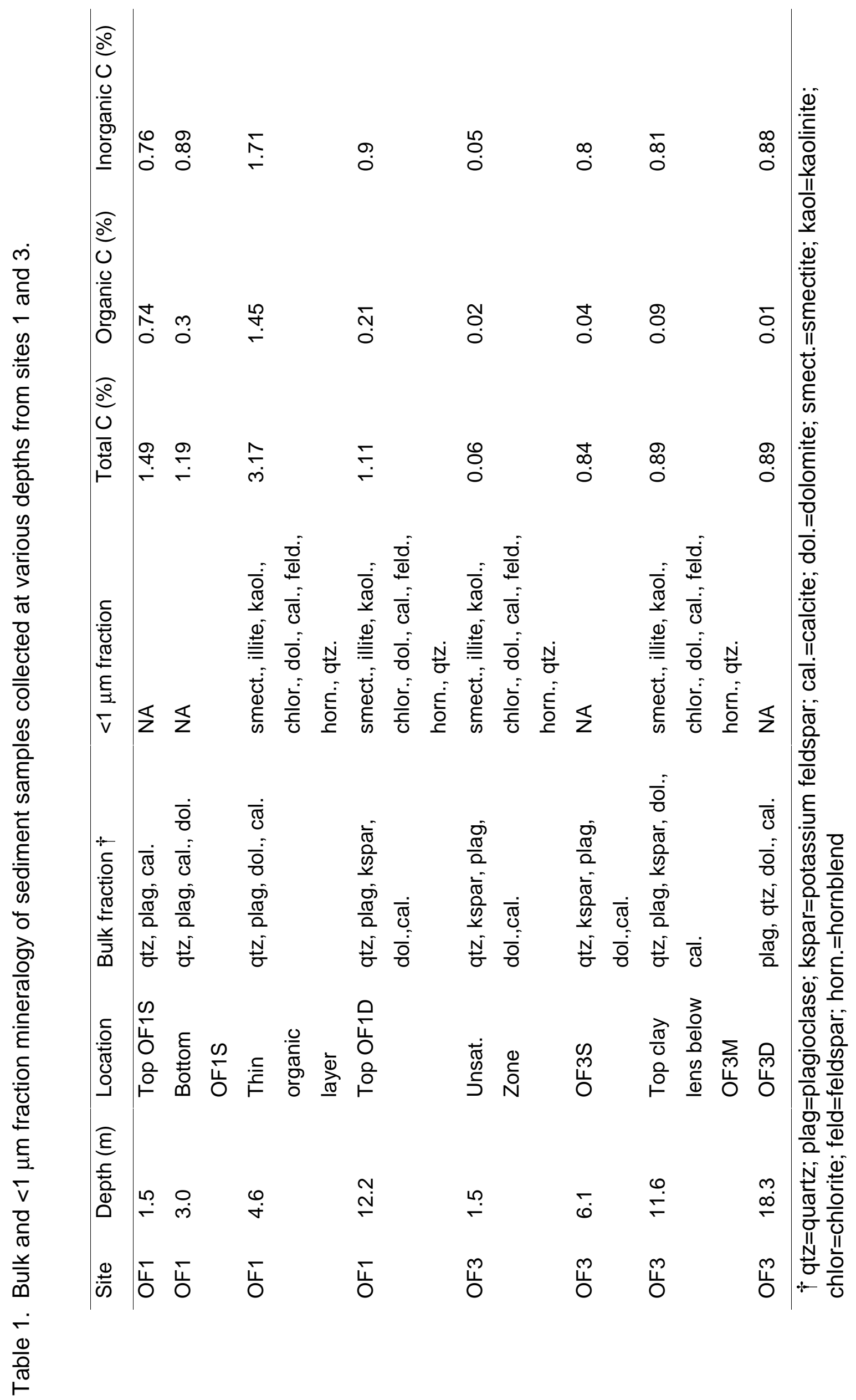


Table 2. Observed and predicted water levels (in meters) and ages (in years) in the Otter Tail transect piezometers based on the MODFLOW/MODPATH simulation, August 1995 measurements, and CFC apparent ages.

\begin{tabular}{lcccc}
\hline Site & Observed & Predicted Water & CFC & Predicted Age \\
& Water Level & Level & Apparent & \\
& August 1995 & & Age & \\
\hline OF1S & 407.5 & 408.1 & $8-11$ & $4-8$ \\
OF1A & 407.6 & 408.1 & 22 & $13-14$ \\
OF1B & 407.5 & 408.1 & $24-25$ & $18-19$ \\
OF1C & 407.6 & 408.1 & $46-47$ & $29-43$ \\
OF1D & 408.7 & 408.1 & $>50$ & $45-53$ \\
OF2S & 409.9 & 410.0 & $\dagger$ & 2 \\
OF2D & 409.5 & 410.0 & $\dagger$ & $38-43$ \\
OF3S & 413.4 & 413.0 & $5-8$ & 3 \\
OF3M & 413.4 & 413.0 & 37 & $14-15$ \\
OF3D & 412.9 & 413.0 & $47-48$ & $39-45$ \\
OF4S & 416.0 & 416.2 & 23 & $2-4$ \\
OF5S & 418.9 & 418.5 & $5-8$ & $1-2$ \\
\hline
\end{tabular}

$\uparrow$ no data available 


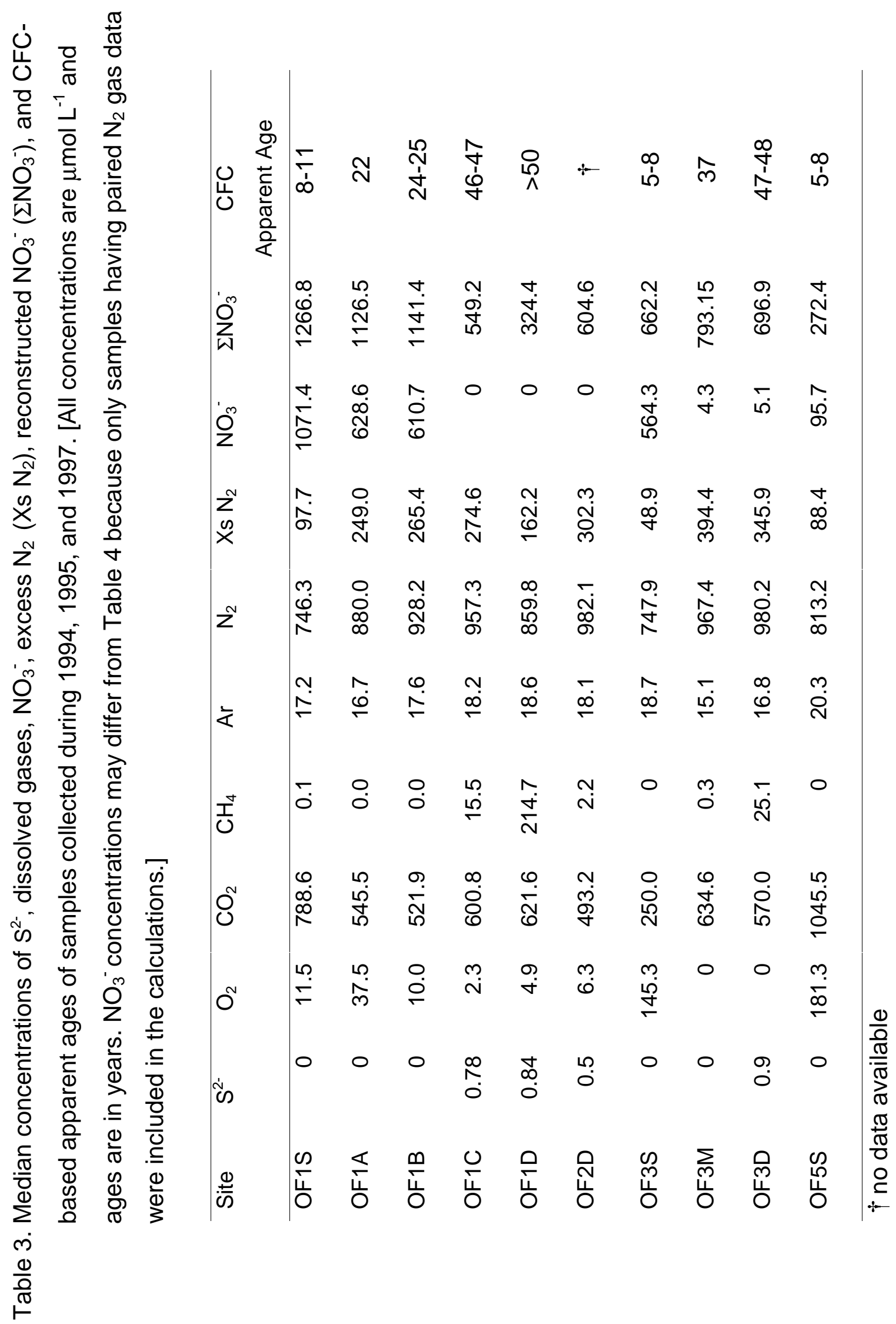




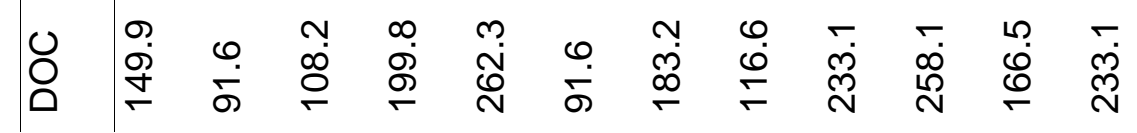

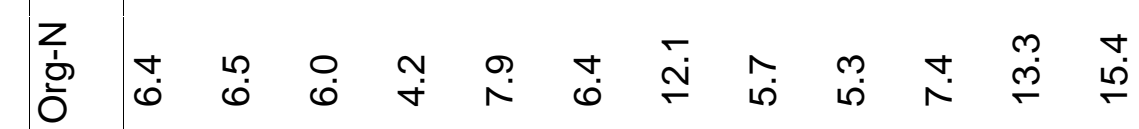

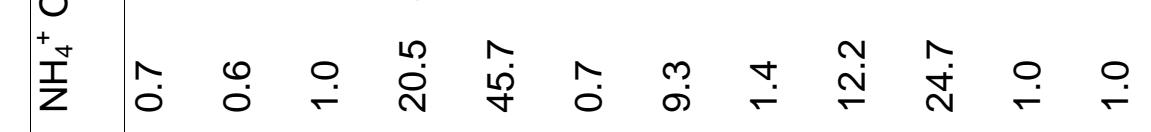

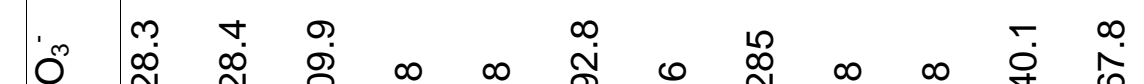

Z

7

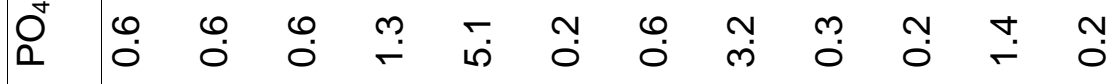

ஸ்

-

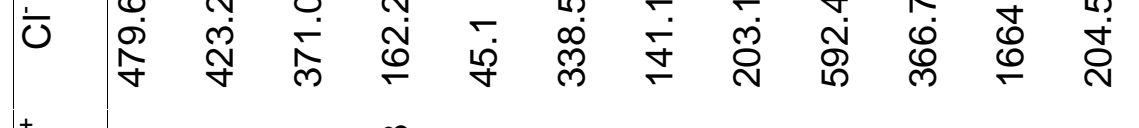

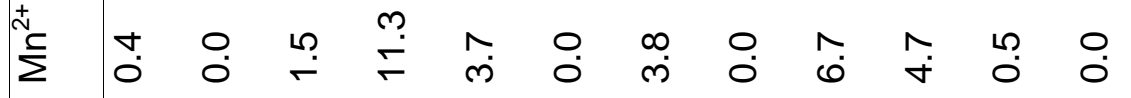

山ٓ

+

\pm மூ

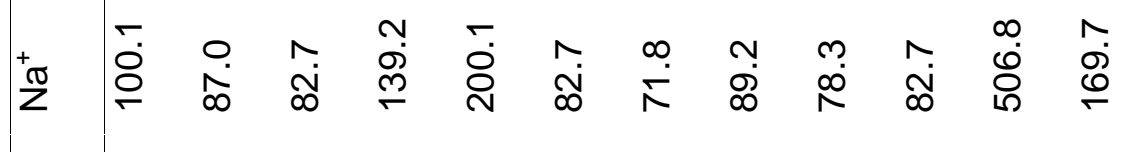

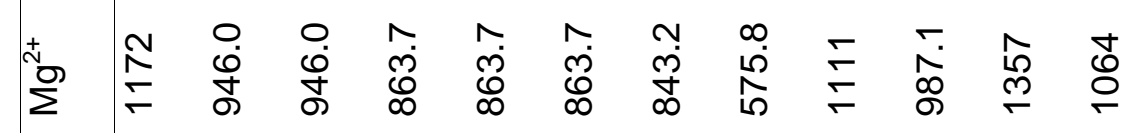

范

ป d

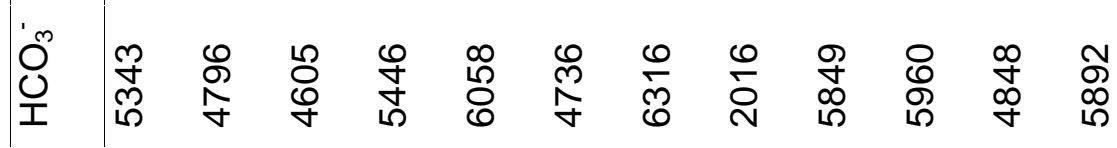

¿

$\stackrel{2}{\frac{1}{2}} \frac{0}{3}$

은 중

.

$\stackrel{0}{2}$

$\frac{1}{0}$

Oั

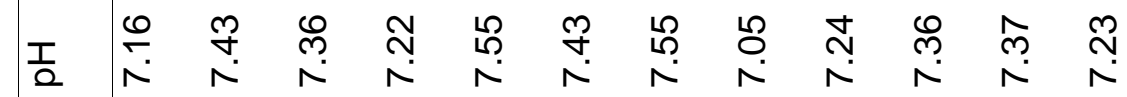

든

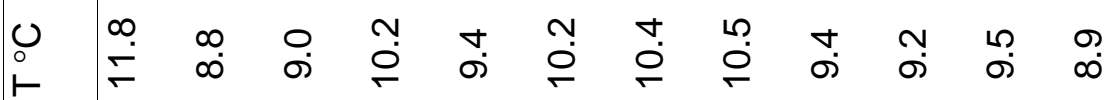

a 
Table 5. Biogeochemical reactions determined from the NETPATH modeling process. Reaction coefficients represent the amount in $\mu \mathrm{mol} \mathrm{L}^{-1}$ of phases entering (positive values) or leaving (negative values) solution.

\begin{tabular}{lrrrr}
\hline & \multicolumn{4}{c}{ Models } \\
\cline { 2 - 5 } Phases & 1 & 2 & 3 & 4 \\
\hline $\mathrm{CH}_{2} \mathrm{O}$ & 1510 & 1510 & 1510 & 1510 \\
$\mathrm{CaCO}_{3}$ & 357 & 259 & 759 & $\dagger$ \\
$\mathrm{CaMg}\left(\mathrm{CO}_{3}\right)_{2}$ & 201 & 250 & $\dagger$ & 379 \\
$\mathrm{~N}_{2}$ & -350 & -350 & -350 & -350 \\
$\mathrm{CaSO}$ & & & \\
$\mathrm{KCl}$ & 23 & 23 & 23 & 23 \\
$\mathrm{KCl}$ & 88 & 88 & 88 & 88 \\
$\mathrm{Ca} / \mathrm{K}$ Exchange & $\dagger$ & -49 & 201 & -179 \\
$\mathrm{Mg} / \mathrm{K}$ Exchange & -49 & $\dagger$ & -250 & 130 \\
$\mathrm{Ca}+\mathrm{Mg} / \mathrm{Na}$ Exchange & -17 & -17 & -17 & -17 \\
\hline
\end{tabular}

$\uparrow$ Phase not included in the model 
Table 6. Denitrification rates from studies of various sand and gravel aquifers. Methods included slurry incubations, in-situ studies, excess $\mathrm{N}_{2}$ analyses, and tracer tests.

\begin{tabular}{|c|c|c|c|}
\hline \multirow[b]{2}{*}{ Studies } & \multirow[b]{2}{*}{ Method } & \multicolumn{2}{|c|}{ Denitrification rate $\mathrm{mmol} \mathrm{NO}_{3}{ }^{-} \mathrm{L}^{-1} \mathrm{yr}^{-1}$} \\
\hline & & Minimum & Maximum \\
\hline \multirow[t]{2}{*}{ Vogel et al. (1981) } & Excess $\mathrm{N}_{2}$ and & NA & 0.0001 \\
\hline & Tritium age dates & & \\
\hline Trudell et al. (1986) & In-situ study & 4.88 & 81.3 \\
\hline Gillham et al. (1990) & In-situ study & 15.0 & 87.6 \\
\hline Bohlke and Denver & Excess $\mathrm{N}_{2}$ and & 0.001 & 0.01 \\
\hline$(1995) \dagger$ & CFC age dates & & \\
\hline \multirow[t]{4}{*}{ Smith et al. (1996) } & Tracer study & 0.13 & 0.31 \\
\hline & Slurry incubation & 0.53 & 1.23 \\
\hline & Soil core incubation & 0.69 & 1.61 \\
\hline & Soil core incubation & 1.38 & 3.22 \\
\hline \multirow{5}{*}{$\begin{array}{l}\text { Tesoriero et al. } \\
(2000)\end{array}$} & Excess $\mathrm{N}_{2}$ and & 0.01 & 0.14 \\
\hline & CFC age dates & & \\
\hline & Excess $\mathrm{N}_{2}$ and & 1.3 & 2.7 \\
\hline & CFC age dates & & \\
\hline & In-situ study & NA & 140 \\
\hline Puckett et al. (2002) & Slurry incubation & 0.99 & 34.46 \\
\hline \multirow[t]{2}{*}{ This study } & Excess $\mathrm{N}_{2}$ and & 0.005 & 0.047 \\
\hline & CFC age dates & & \\
\hline
\end{tabular}

$\uparrow$ Rates calculated from data provided by Bohlke and Denver 


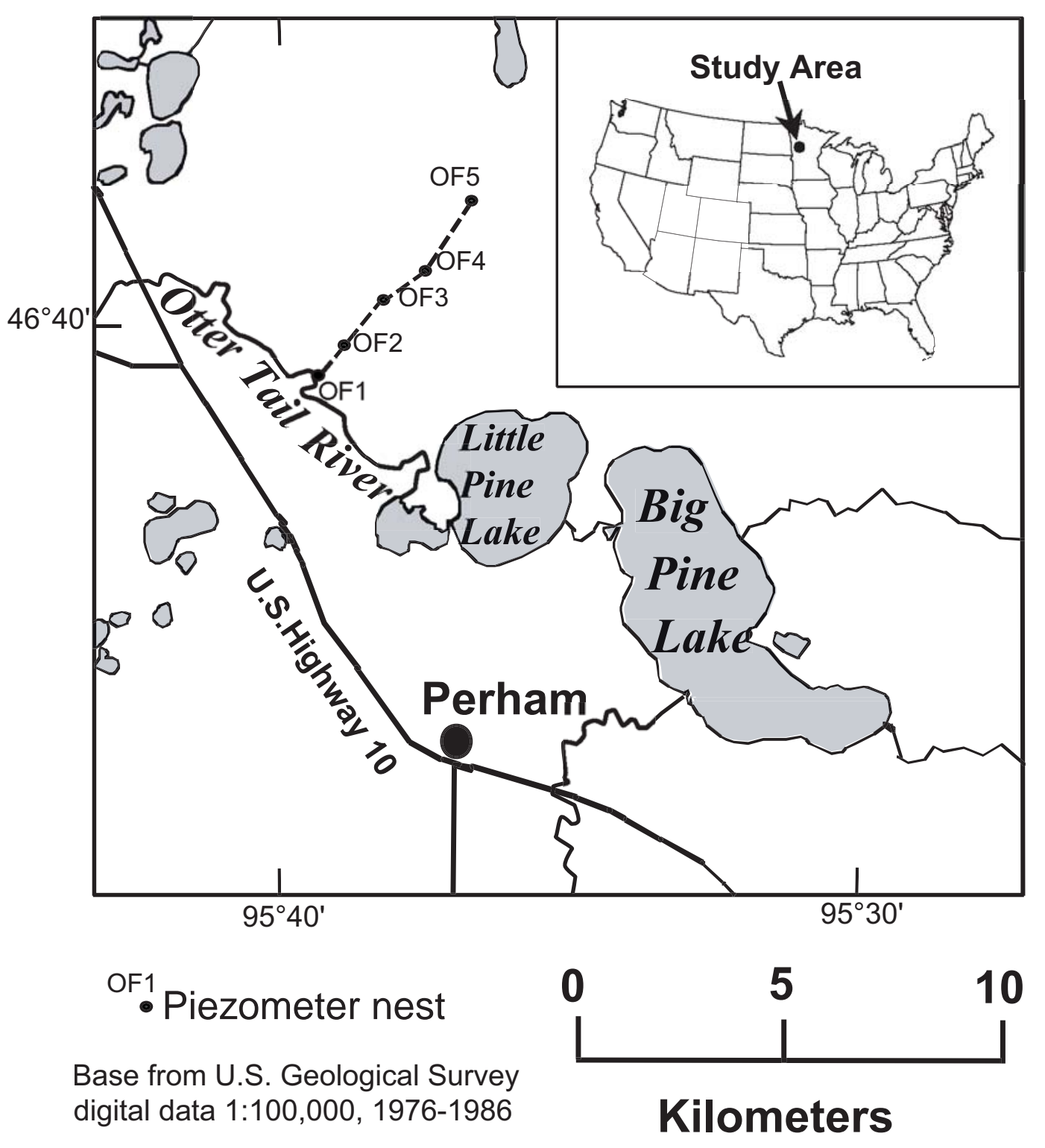

Figure 1. Location of the study area north of the Otter Tail River. 

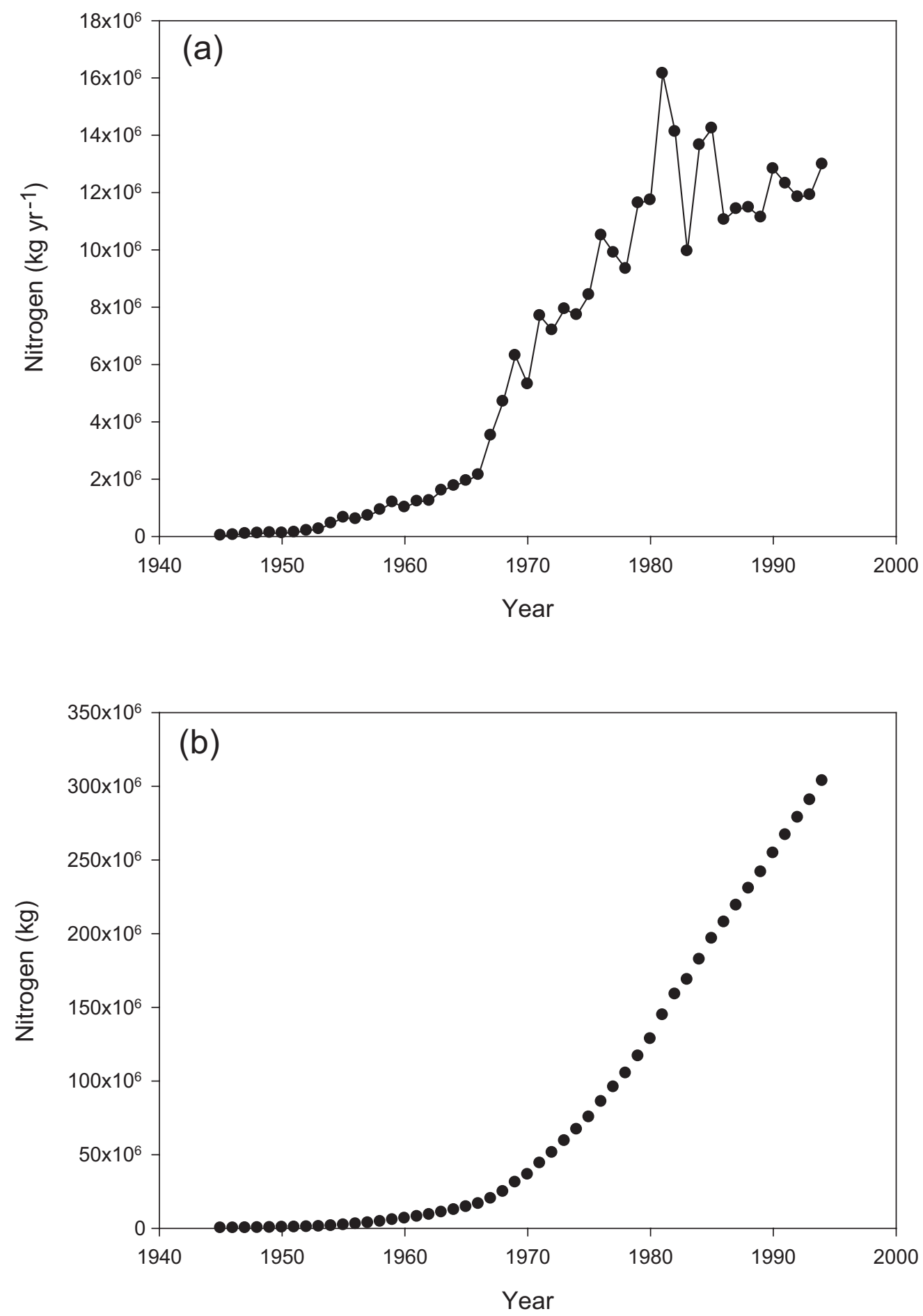

Figure 2. (a) Annual fertilizer nitrogen applications in Otter Tail county since 1945, and (b) cumulative nitrogen applications during the same period. 


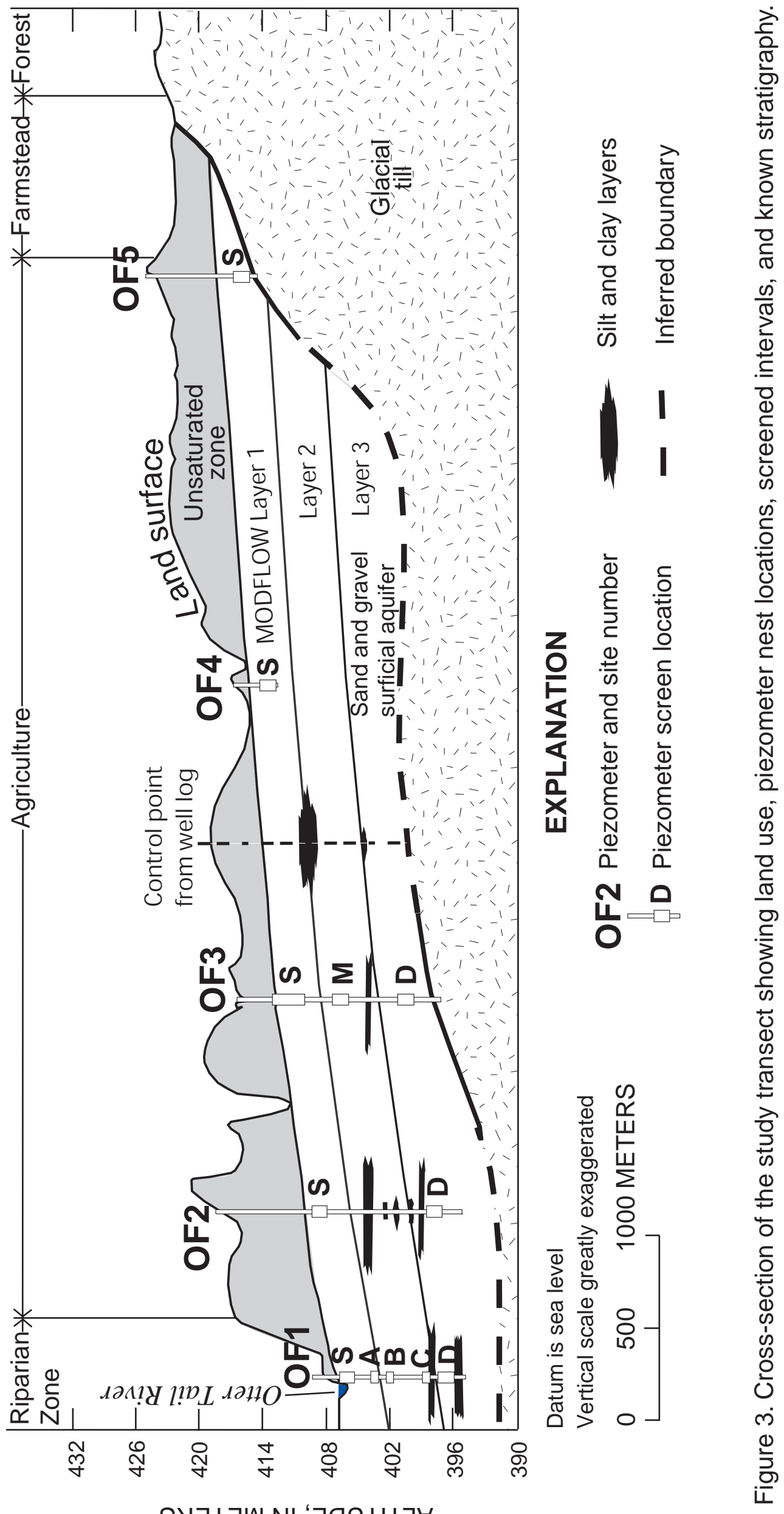



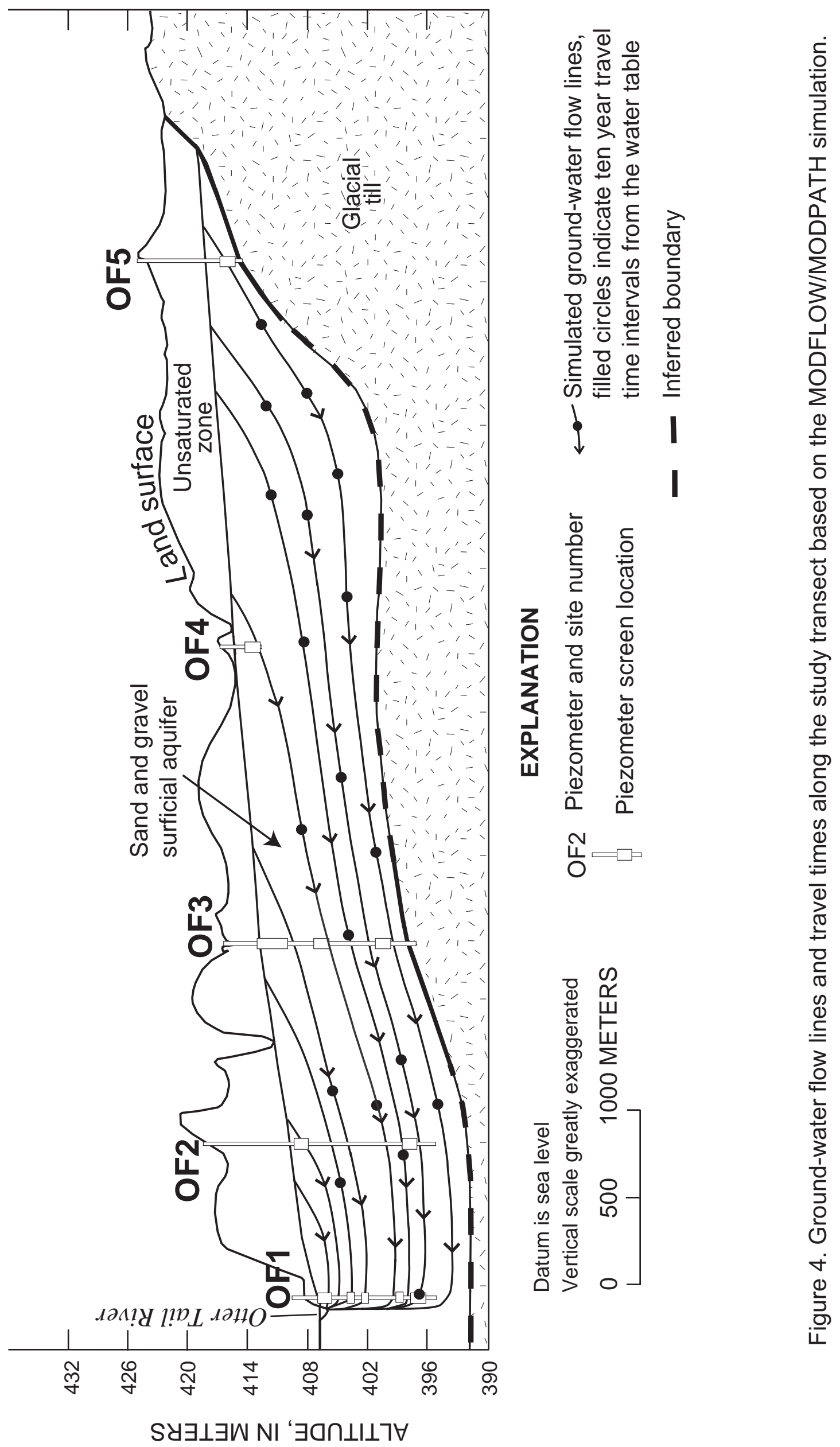

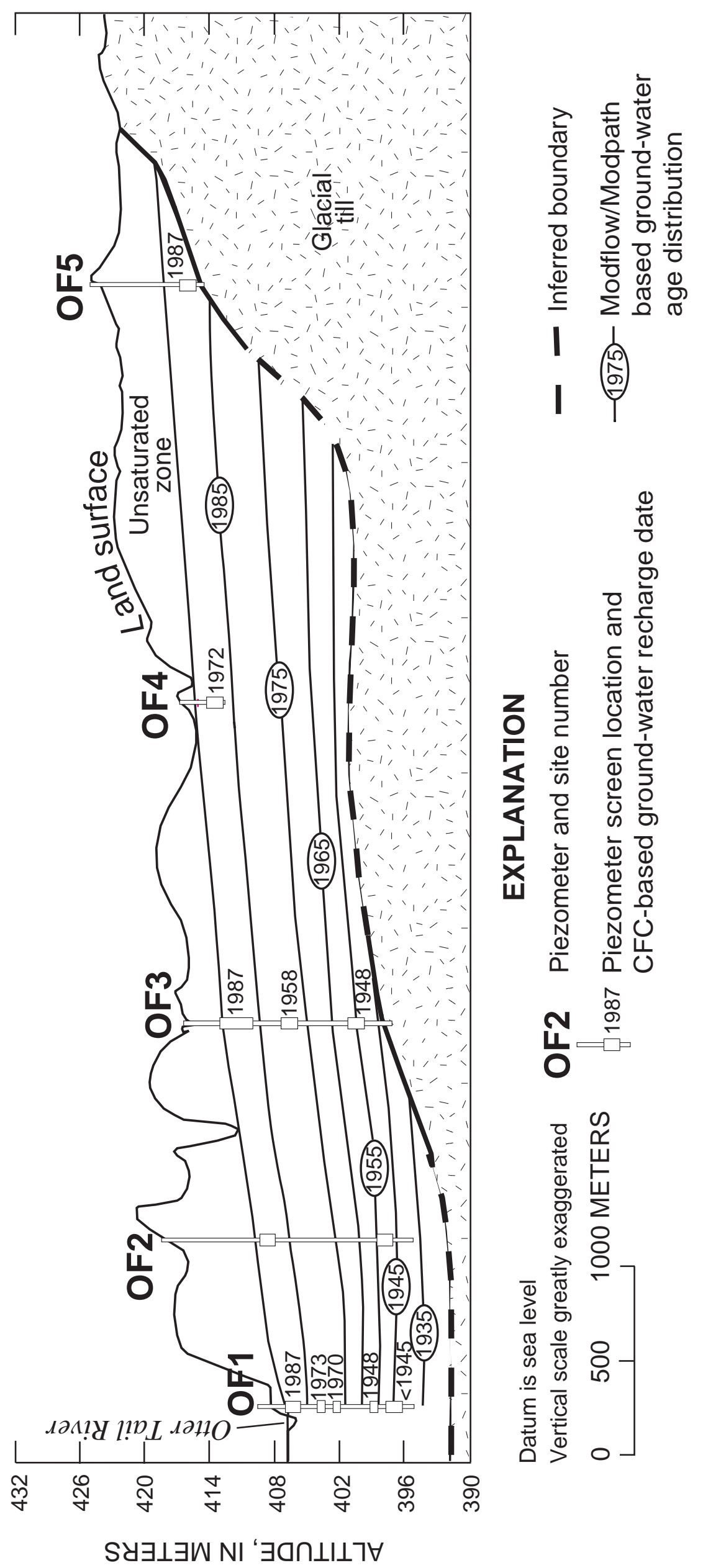

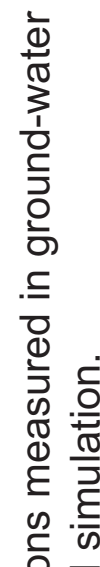

음

苋这

잉

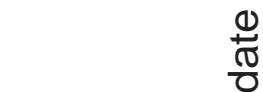

O)

는

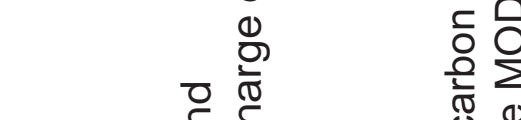

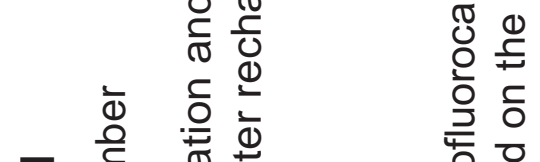

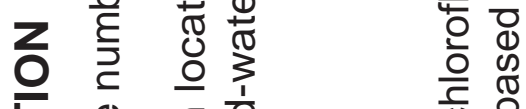

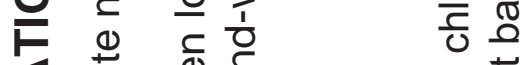

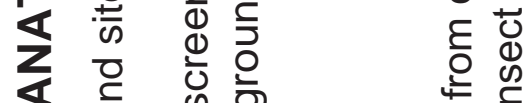

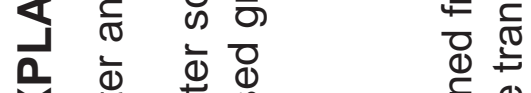

ய

ป ह ํำ

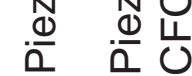

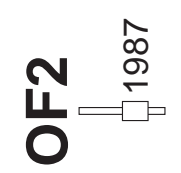

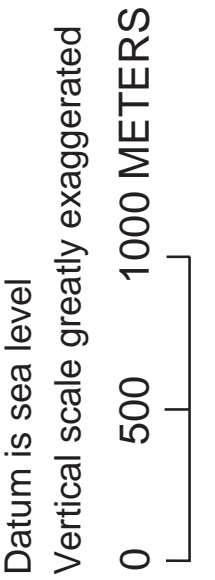

$\frac{0}{0} \frac{0}{0}$

क)

क)

중 은

ब.

党 $\frac{0}{0}$

Ф

过 $\frac{\mathbb{N}}{\frac{N}{\sigma}}$

$\sum_{0}^{\pi} \frac{\pi}{0}$

을 ฮ

음 읃

तथ

흥

远 $\frac{\varepsilon}{\sqrt{x}}$

เ

은 


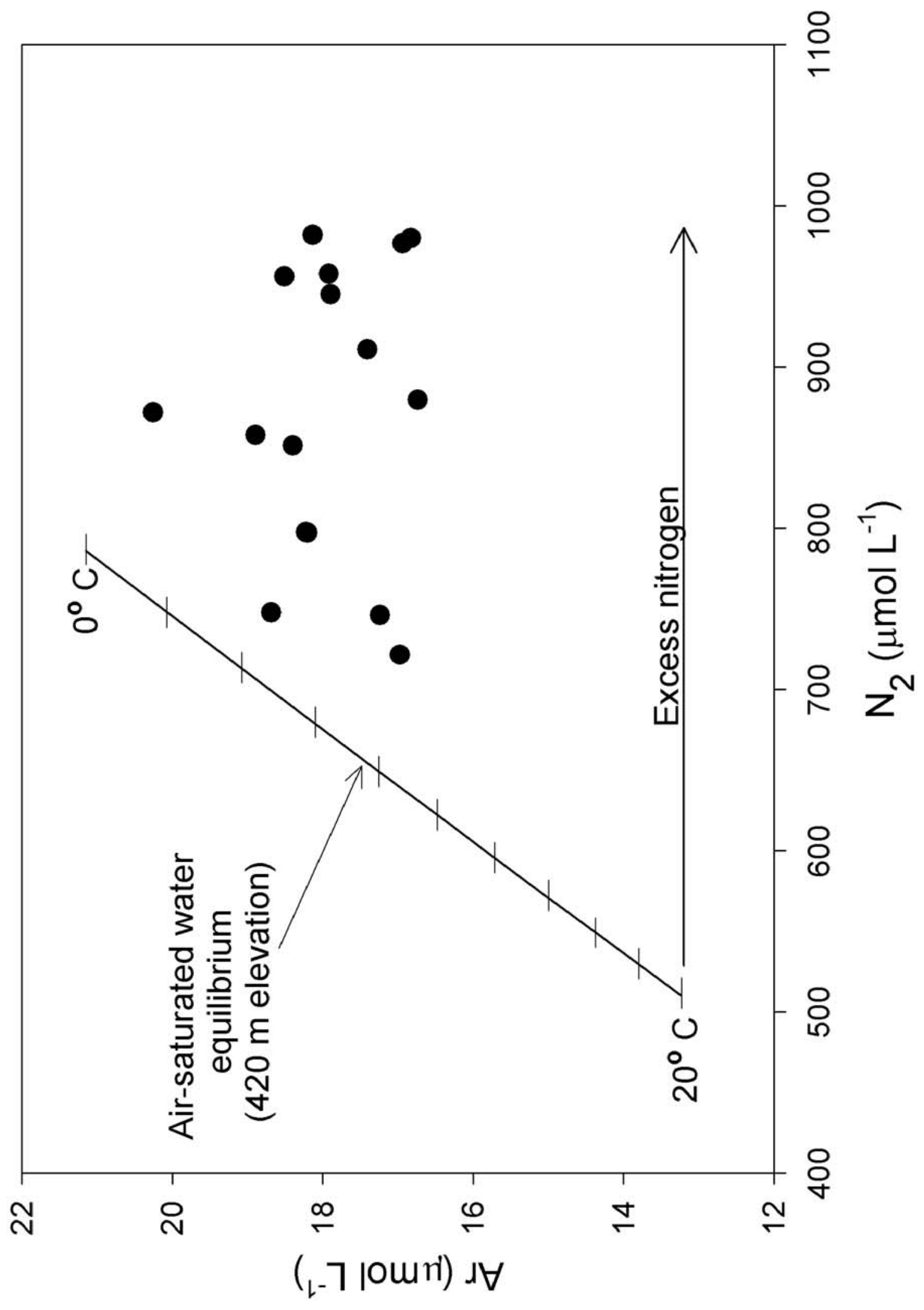

ত্

율

$\neq 0$

등

๑ ㅇㅇㅇ

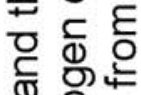

त

匇 。

的苋

중한

ते $x$

n.

ब 등

O

约

응

잉

든

흔

이을 울

บั

원

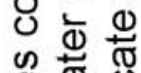

क त

긍

है

क त.

눈 吾

क क के

을 훙

뜬

엉

눙

0 흥

ต

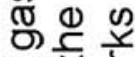

ฮे 을

O)

일

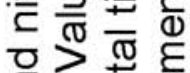

สิ का ठ

드는든

원 꽁ํํ

ம

을 


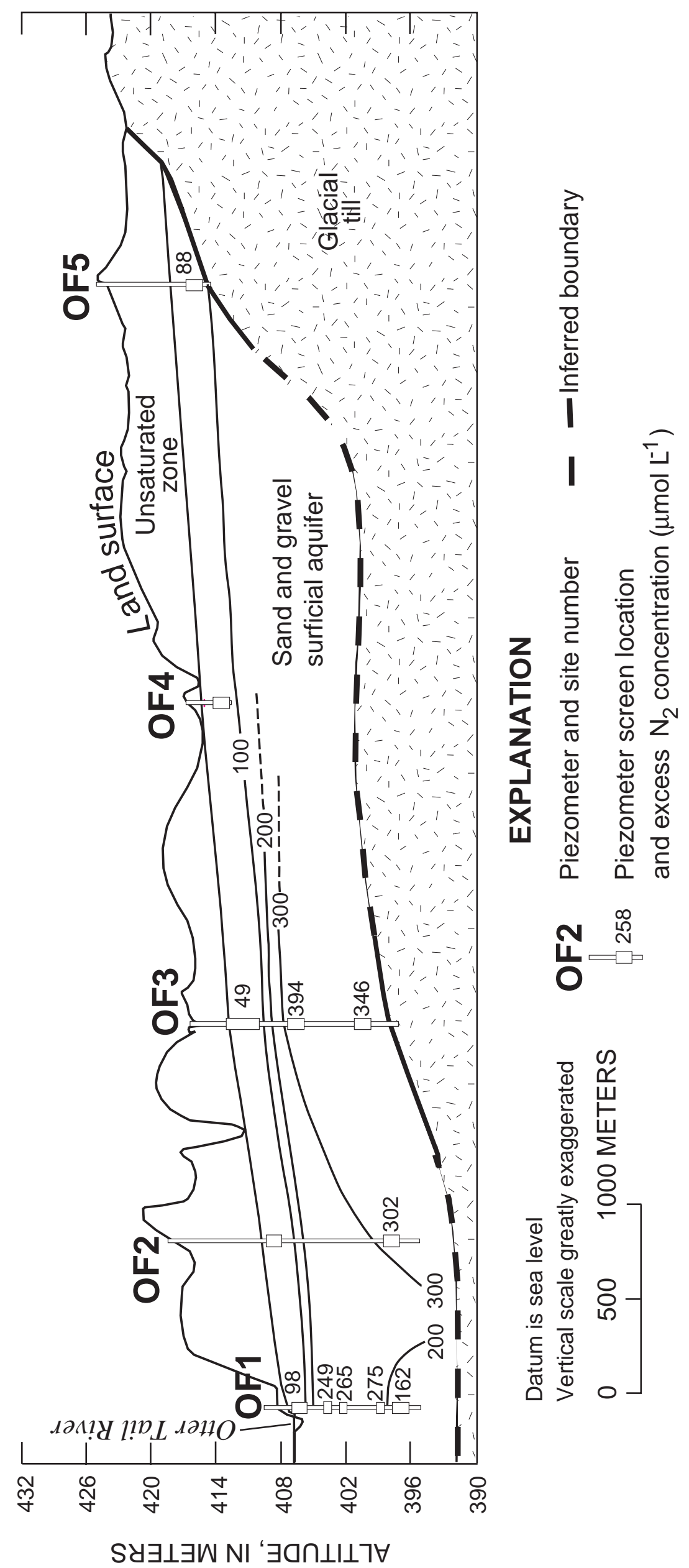

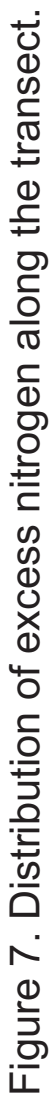




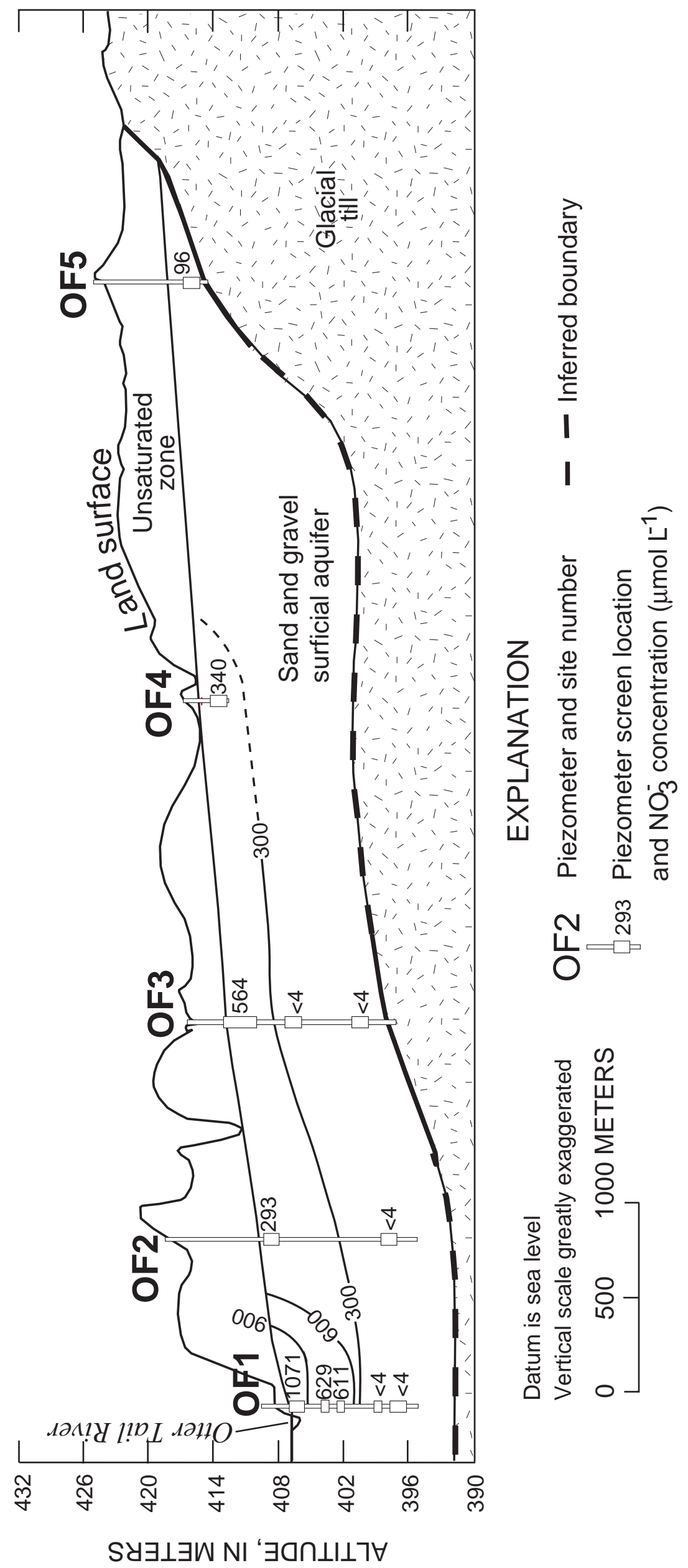

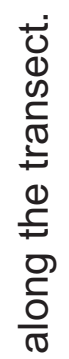

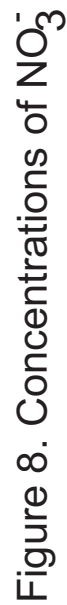


(a)

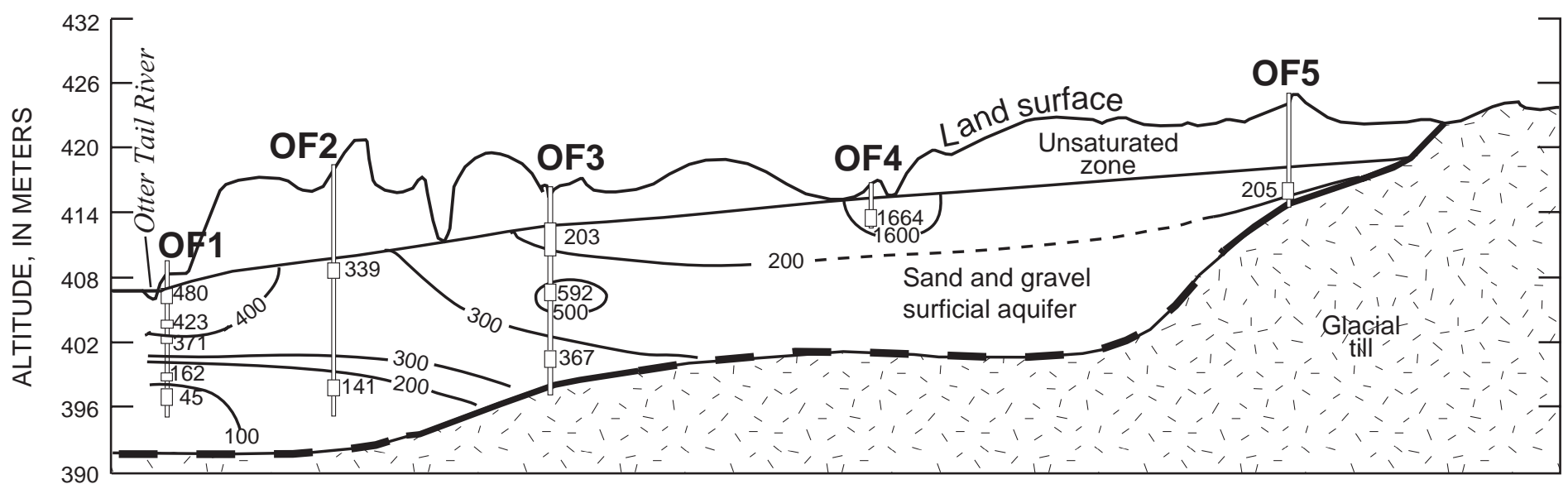

Datum is sea level

EXPLANATION

Vertical scale greatly exaggerated

$0 \quad 500 \quad 1000$ METERS

OF2 Piezometer and site number - - inferred boundary

I367 Piezometer screen location

and $\mathrm{Cl}^{-}$concentration $\left(\mu \mathrm{mol} \mathrm{L}{ }^{-1}\right)$

(b)

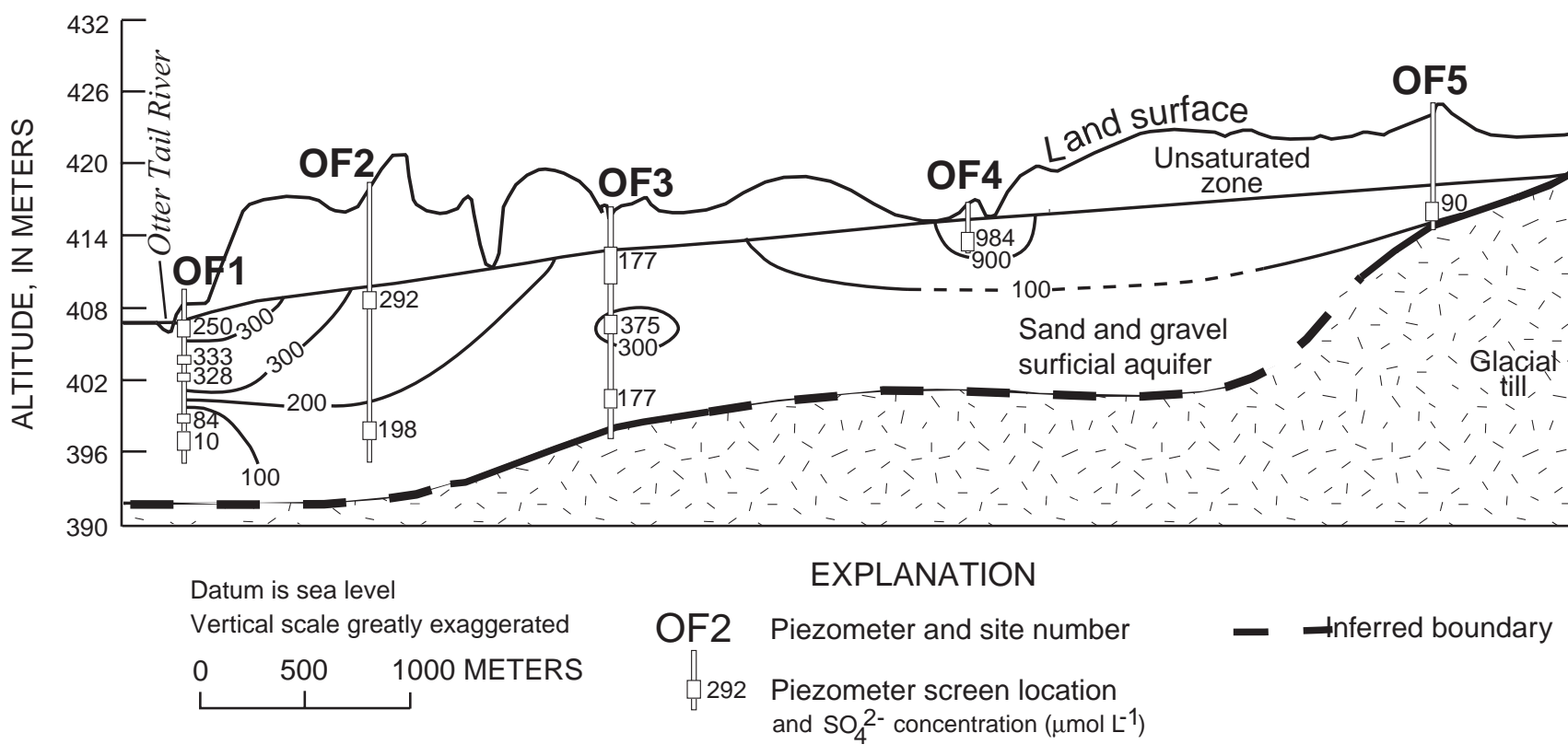

Figure 9. Distribution of (a) $\mathrm{Cl}^{-}$and (b) $\mathrm{SO}_{4}^{2-}$ along the transect. 


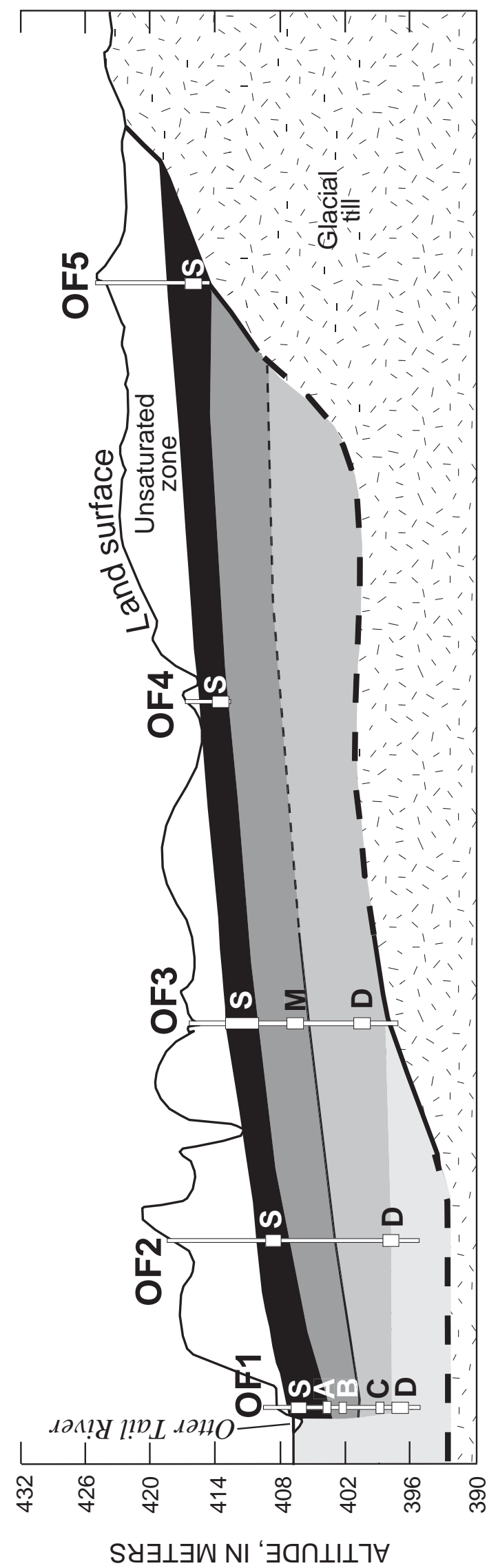

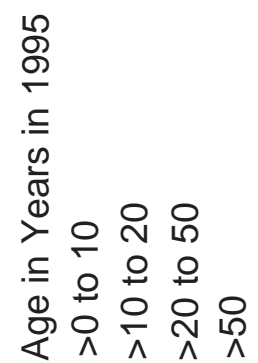

$\square \square \square \square$

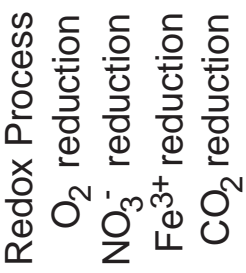

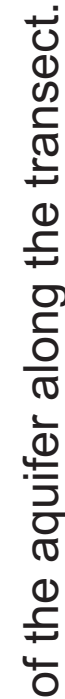

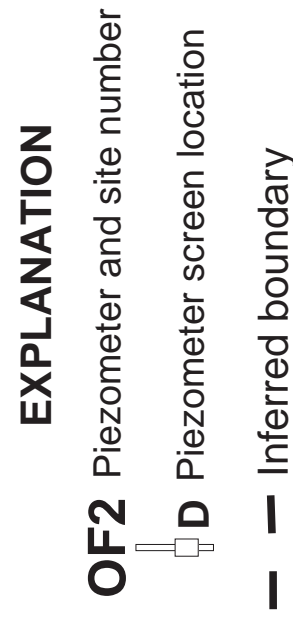

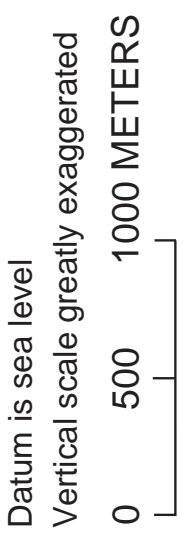

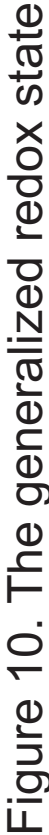




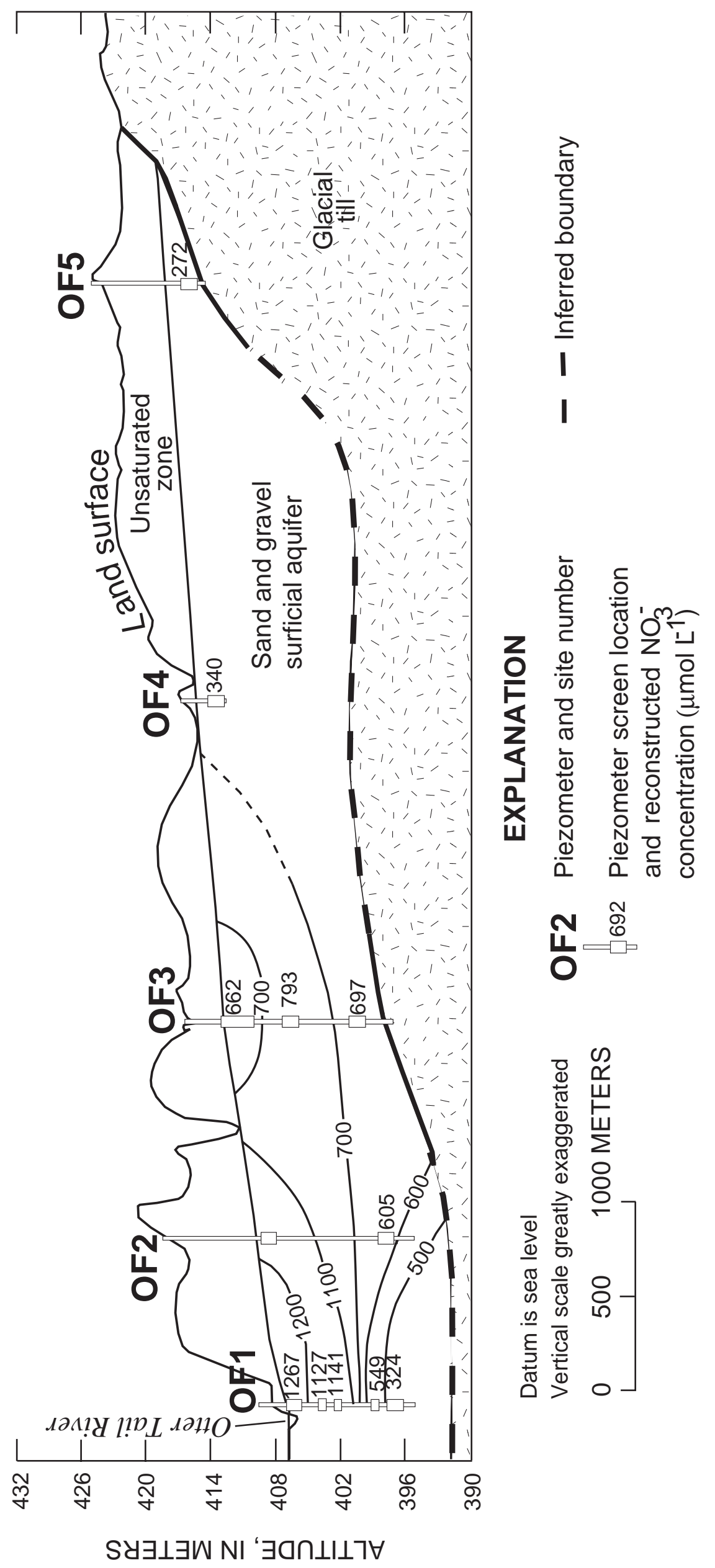

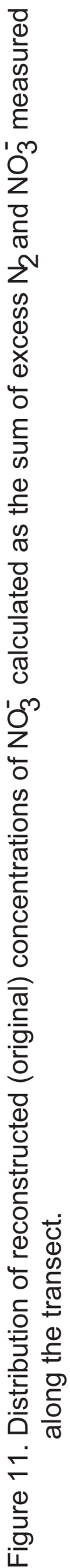

